\title{
New stratigraphic and genetic model for the dolomitic Cretaceous Pinda reservoirs in Angola

\author{
Part II - Compelling arguments \\ against early dolomitization and early leaching
}

\author{
Bruno GRANIER ${ }^{1}$
}

\begin{abstract}
This is the second contribution to the stratigraphic and genetic model of the Pinda Group. The mid-Cretaceous Pinda Group of the Congo basin in the northern Angolan offshore is a transgressive supersequence. Its lower part is made of Bufalo and Pacassa facies that correspond respectively to mixed and calcareous-dolomitic grain-dominated fabrics. Both facies were strongly diagenetically altered, mostly by dolomitic replacement and leaching. Contrary to opinions expressed by other authors that both styles of alteration are early diagenetic phenomena, there is substantial evidence for a burial origin with dolomitic replacement and leaching of calcite having started at depths not less than $150 \mathrm{~m}$ and $400 \mathrm{~m}$, respectively.
\end{abstract}

\section{Key-words:}

- Angola;

- Pinda;

- Albian;

- Cenomanian;

- reservoirs;

- dolomite;

- replacement;

- cementation;

- mechanical compaction;

- chemical compaction;

- leaching

Citation: Granier B. (2019).- New stratigraphic and genetic model for the dolomitic Cretaceous Pinda reservoirs in Angola. Part II - Compelling arguments against early dolomitization and early leaching.Carnets Geol., Madrid, vol. 19, no. 4, p. 47-70.

Résumé : Nouveau modèle stratigraphique et génétique pour les réservoirs dolomitiques du Pinda (Crétacé, Angola). I le Partie - Preuves irréfutables contre une dolomitization et une dissolution précoces.- II s'agit ici de la deuxième contribution au modèle génétique et stratigraphique du Pinda. Le Groupe Pinda du Crétacé moyen constitue une mégaquence transgressive au large de la partie septentrionale de l'Angola dans le bassin du Congo. Sa partie inférieure est constituée par les faciès Búfalo et Pacassa qui correspondent respectivement à des roches sédimentaires mixtes et calcaires-dolomitiques à dominante grenue. Ces deux types de sédiments ont subi de fortes altérations diagénétiques, essentiellement par du remplacement de la calcite par de la dolomite et par dissolution de la calcite restante. Contrairement aux opinions exprimées par d'autres auteurs selon lesquelles ces processus sont attribuables à une diagénèse précoce, il existe un faisceau d'arguments solides en faveur d'une origine liée au processus d'enfouissement avec notamment un remplacement par de la dolomite et de la dissolution ayant débuté respectivement à des profondeurs d'enfouissement d'au moins $150 \mathrm{~m}$ et $400 \mathrm{~m}$.

1 "Cátedra Franco-Brasileira no Estado de São Paulo 2015", UNESP - Universidade Estadual Paulista, Center for Geosciences Applied to Petroleum (UNESPetro), Caixa Postal 178, Av. 24 A, no. 1515, Bela Vista, CEP13506-900 Rio Claro - SP (Brazil);

Dépt. STU, Fac. Sci. Tech., UBO, 6 avenue Le Gorgeu, CS 93837, F-29238 Brest (France)

bgranier@univ-brest.fr

Published online in final form (pdf) on February 15, 2019

[Editor: Michel MOULLADE; language editor: Robert W. SCOTT; technical editor: Bruno GRANIER] 
Mots-clefs :

- Angola :

- Pinda ;

- Albien ;

- Cénomanien ;

- réservoirs

- dolomie ;

- remplacement ;

- cimentation ;

- compaction mécanique

- compaction chimique ;

- dissolution

Resumo: Novo modelo estratigráfico e genético para os reservatórios dolomíticos Pinda (Cretáceo, Angola). Parte II - Provas irrefutáveis contra a dolomitização e a lixiviação precoces.- Esta é a segunda contribuição ao modelo genético e estratigráfico do Pinda. O Grupo Pinda, Cretáceo médio da Bacia do Congo em região costa afora do norte angolano, constitui uma supersequência transgressiva. Sua parte inferior é composta pelas fácies Búfalo e Pacassa que correspondem, respectivamente, a tramas mistas e calcário-dolomíticas dominadas por grãos. Tais fácies sofreram fortes alterações diagenéticas, sobretudo por processos de dolomitização (substituição dolomítica da carbonato de cálcio) e dissolução da cálcita restante. Contrariamente a opiniões de outros autores que interpretaram tais processos como tendo sido ligados à diagênese precoce, há indícios concretos de que eles tiveram uma origem associada ao soterramento, tendo a substituição dolomítica e a dissolução sido iniciadas em profundidades não menores que $150 \mathrm{~m}$ e $400 \mathrm{~m}$, respectivamente.

\section{Palavras-chave:}

- Angola;

- Pinda;

- Albiano;

- Cenomaniano;

- reservatórios:

- dolomito;

- substituição;

- cimentação;

- compactação mecânica;

- compactação química;

- dissolução

\section{I ntroduction}

In Angola's offshore licence blocks 2 and 3 (Fig. 1), carbonate rocks of the Bufalo, Pacassa and even Punja facies of the Pinda Group (Fig. 2) are commonly dolomitic, resulting mostly from dolomitic replacement of calcium carbonate (both aragonite and calcite) and partly from dolomitic cementation of porosity. Dolomitized Bufalo and Pacassa facies represent the best reservoir rocks in terms of porosity and permeability. Where such rocks were not fully dolomitized, later dissolution phases eventually affected the non-dolomitic parts, i.e., mostly residual calcite, and further enhanced porosity and permeability. In contrast, later cementation, including anhydrite and hightemperature saddle dolomite, has significantly reduced both porosity and permeability. Understanding these processes and their timing relative to the oil and gas charge of the reservoirs is a requisite for a better assessment of exploration risk and production capacity of Angola's Pinda structures.
Contrary to opinions expressed by other authors (STARK, 1991; EICHENSEER et al., 1999) that dolomitic replacement and leaching are early diagenetic phenomena, this second contribution to the stratigraphic and genetic model of the Pinda Group provides substantial evidence for a burial origin of both styles of diagenetic alteration.

\section{Petrographical background}

According to STARK (1991, p. I-39), "Reservoir qualities in the Albian $A$ and $B$ are the result of polyphasic dissolution of the calcareous elements, followed by strong dolomitization (dissolution of the allochems and of the calcareous cements). The dissolution mechanism was closely related to early meteoric water infiltration within the carbonate granular network. Porosity is mainly vuggy and/or intercrystalline and is locally increased by fracture porosity. Dissolution was followed by a number of cementation phases which led to dolomitization, anhydritization and calcitization. This cementation, however, did not totally obliterate the earlier dissolution porosity." 


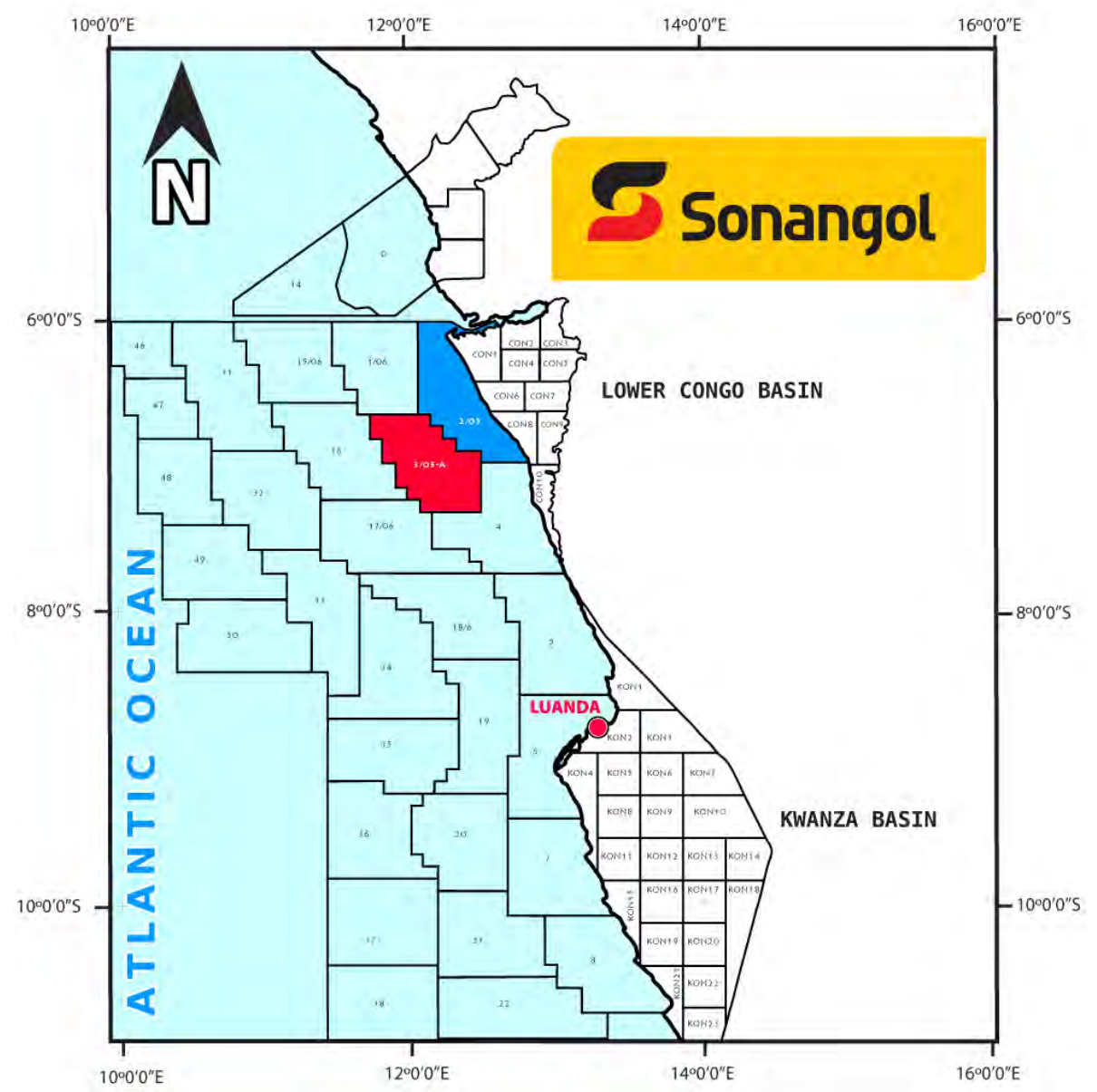

Figure 1: Location of offshore licence blocks 2 (blue) and 3 (red) in Angola's concessions (excerpt from GAD 201501-DMC0001-I-A),

excerpt from GRANIER, 2017.

carnets Geol. 19 (4)

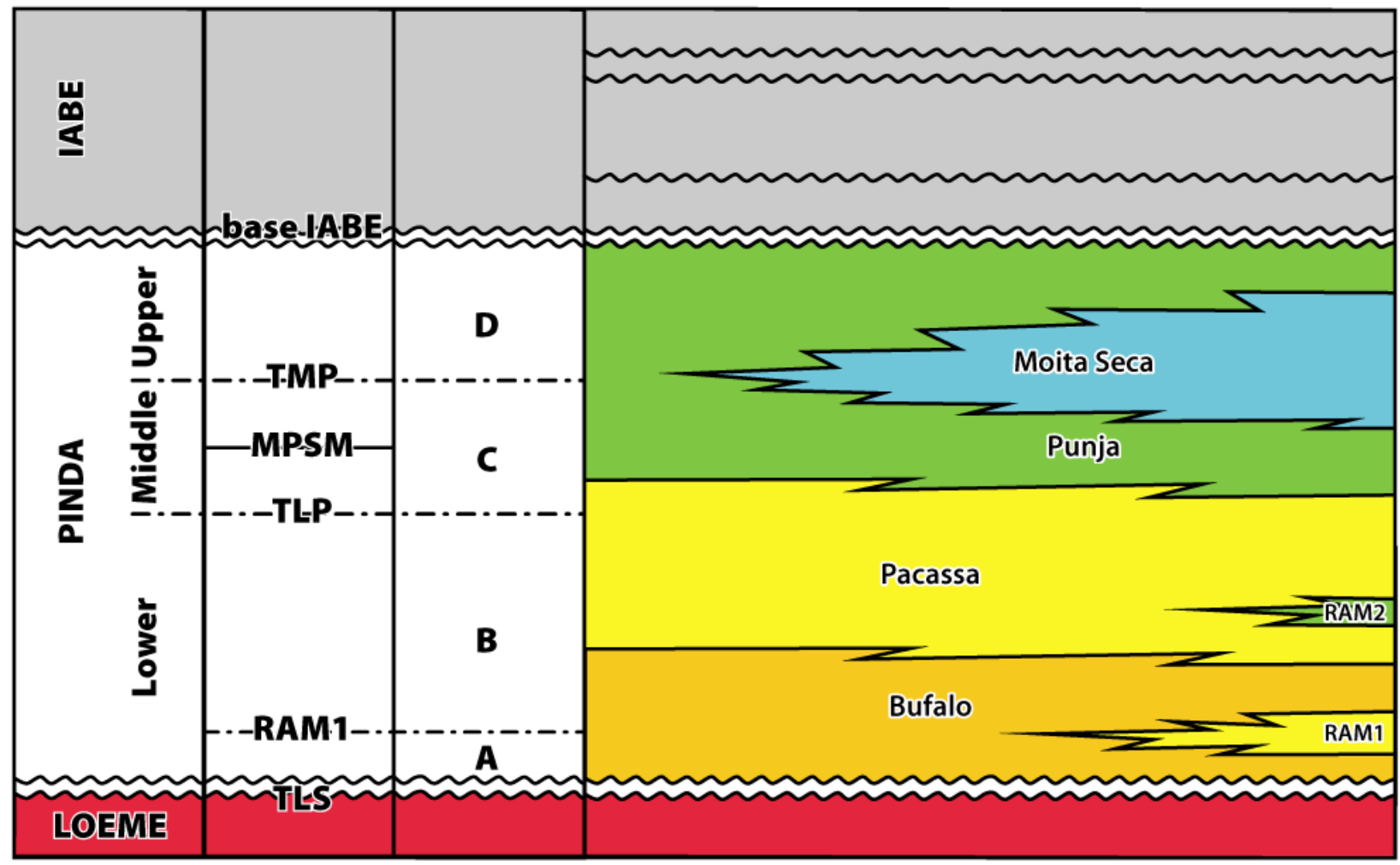

Figure 2: Pinda stratigraphic nomenclature (formations, members, facies, and key surfaces), excerpt from GRANIER, 2017. 
According to EICHENSEER et al. (1999), "The combined stratigraphic and geochemical approach allowed us to determine the Pinda Group dolomites as early diagenetic in origin, whereas fluid inclusion and oxygen isotope analysis alone suggested a late burial dolomite formation. Dolomite neomorphism at higher burial temperatures modified most of the original geochemical signatures of early, near-surface dolomitization. Cathodoluminescence data and trace element analysis suggest that dolomitization was associated with gradually decreasing pore water salinity. Accordingly, barrier oolites were completely dolomitized and developed intercrystalline porosity during the earliest stages of diagenesis. At a later phase of early diagenesis, as waters became less saline and undersaturated with respect to calcium carbonate, fabric-selective dissolution of the remaining calcareous components occurred. The decrease in pore water salinity and associated porosity generation are genetically linked with high-frequency events of relative sea level lowering."

Since the early 1990s the present author (GRANIER, 2009, and earlier unpublished reports) has always taken the exact opposite stance to both STARK (1991) and EICHENSEER et al. (1999), based on observations such as the fact that "fabric-selective dissolution" in the Pinda Group reservoirs always postdates stratiform stylolites (see $\S 8$.). The present study provides alternative evidence to the effect that most, if not all, the dolomitization stages, as well as calcite leaching, occurred in fact during the rather late stages of diagenesis rather than "during the earliest stages of diagenesis" as stated by EICHENSEER et al. (1999). Neither are they related to "early meteoric water infiltration" (op. cit.). "The most likely source for the Mg of the Pinda dolomites was" neither meteoric water, marine water nor marinederived brines but probably the "brine from the polyhalites of the underlying Loeme Salt" (GRANIER, 2009). It will be demonstrated that STARK'S statements (1991) and some arguments used by EICHENSEER et al. (1999) to support their hypotheses are erroneous.

\section{Material, terminology, and method}

\section{3a. Material}

The original material (thin sections, cores, well logs) is the property of Sociedade Nacional de Combustíveis de Angola Empresa Pública - Sonangol E.P. It was not available for re-study but a special agreement granted permission to re-use a set of older photomicrographs (GRANIER, 2017: PIs. 1-7) and other data (op. cit.). These traditional silver emulsion microphotographs of thin sections with transmitted light (TL) and polarized light (PL analyzed) were part of the standard petrographic analyses. They are a primary technical or scientific source material. Nowadays, electro- nic imagery makes it easy to capture more images. In addition to TL and PL silver emulsion microphotographs of thin sections, the present author used some microphotographs with reflected light (RL), which were usually poorly contrasted. Nowadays, electronic imagery and associated tools permit to "optimize" such RL photos, either scans of silver emulsion photos or recently captured electronic photos, that will be referred to as "photos with enhanced reflected light" (ERL); they also permit various combinations (Figs. 3, 4.A-D).

\section{B. TERMI NOLOGY}

Carbonate rocks are made of a combination of grains (mostly calcareous allochems, some quartz and feldspar), organic framework (building, binding, or entrapping as baffles), mud (micrite), pore spaces (occupied either by gas, brine or oil/bitumen), insoluble residues (e.g., iron oxide, clay minerals, and organic matter), cements (crystals), and "replacement" (crystals). "Dolomitization" is commonly seen as replacement, although it may include some cementation:

1. Primary dolomite (also referred to as "depositional" dolomite, early dolomite, synsedimentary dolomite, ...), which is either bacterially induced, i.e., biocements interspersed with bacterial EPS (extracellular polymeric substances) and which is considered as a rather marginal phenomenon, or the result of cementation (i.e., crystals growing centripetally in pores);

2. Secondary dolomite (also referred to as late dolomite, post-depositional dolomite, ...), which is the result of either replacement (i.e., a mosaic of crystals with associated intercrystalline porosity) or cementation (i.e., crystal overgrowths or crystals growing centripetally in pores and open fractures). During the replacement of a calcareous allochem, the intragranular microporosity is filled with dolomite; such a dolomite "microcement" cannot be distinguished from the coeval replacing dolomite.

This terminology is not precise and can be advantageously replaced by either "dolomitic replacement" or "dolomitic cementation".

\section{C. Method}

As already stated in the first part of this report (GRANIER, 2017), "The combination of petrographic observations using a standard polarizing microscope with transmitted light, crossed polars, reflected light with a "white card" (...), eventually supplemented by cathodoluminescence analyses (...), allows discrimination of dolomitic replacement (reddish brown, locally with inclusions) leading to a porosity increase from later dolomite (dull), calcite (orange and yellow) and anhydrite (non-luminescent) cementations leading to a porosity decrease". 

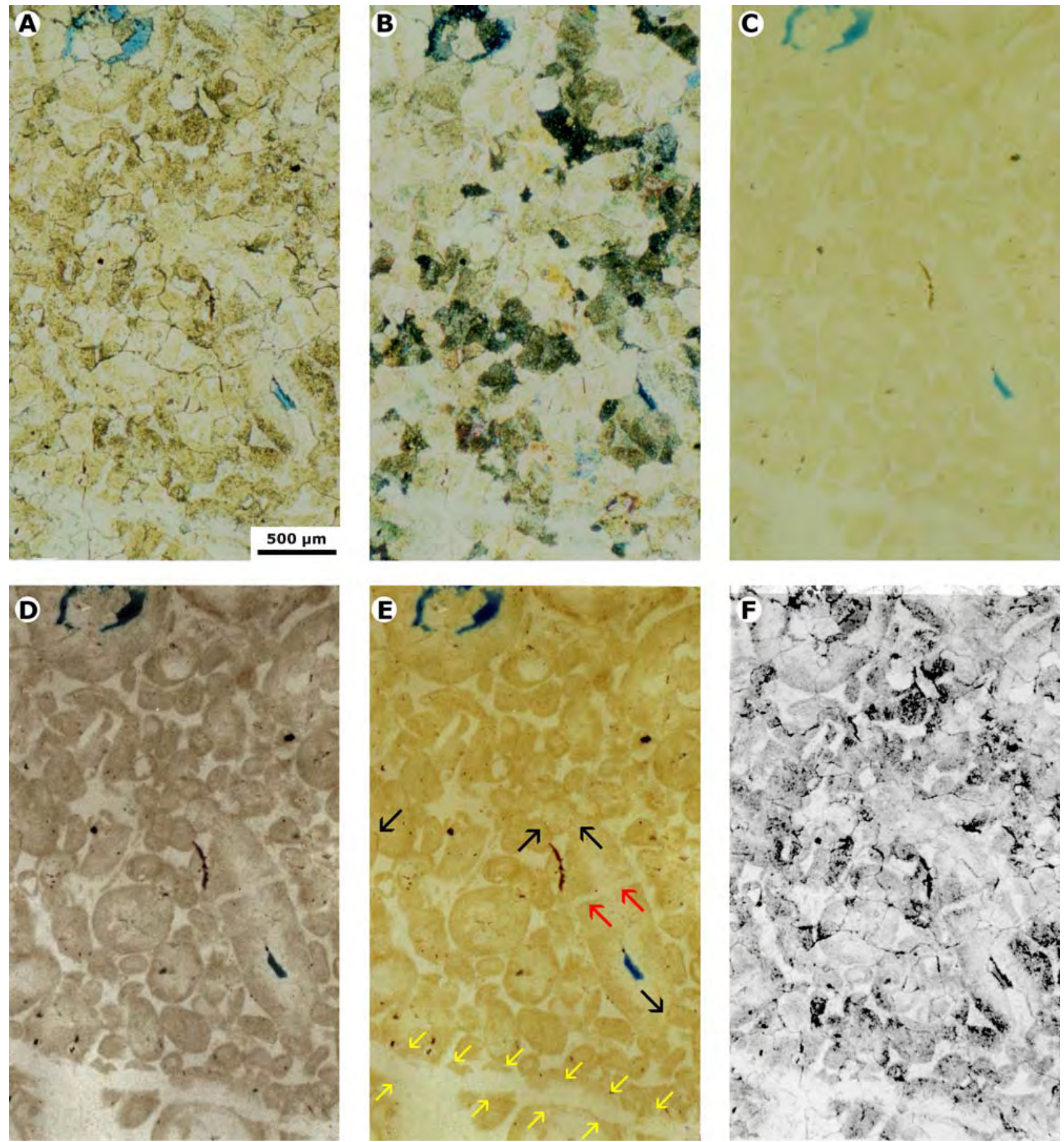

Figure 3: Pinda Group. A-F) Dolograinstone: A) TL transmitted light; B) PL polarized light (analyzed); C) RL reflected light; D-E) ERL enhanced reflected light; F) a combination of TL and RL. Black arrows: sutured contacts; red arrows: grain break; yellow arrows: fracture. For confidentiality purposes the sample depths and the name of wells are not provided.

Recognition of microfacies, both depositional and diagenetic (grains, matrix, porosity, cement, replacement), entails more or less complex approaches. Where dolomite rhombs are few and scattered in the thin section, the microfacies was defined using the DUNHAM (1962) classification or the expanded version by EMBRY and KLOVAN (1971). Where dolomitization is more extensive the Dunham texture label comes with the prefix "dolo-"; if the primary texture cannot be recognized it is referred to as a dolostone (or dolo- crystalstone). Very often, not only in the case of the Pinda Group, the fine crystals of the dolomicrite mosaic in dolomudstones or dolowackestones resulted from the replacement of micritic mud whereas the coarser crystals of the dolosparitic mosaic in the dolograinstones resulted from the replacement of allochems and cement. The mosaic pattern results from the initial random/scattered arrangement of the crystallization nuclei/seeds. Considering the dolograinstones, ghosts of grains are often visible in transmitted 

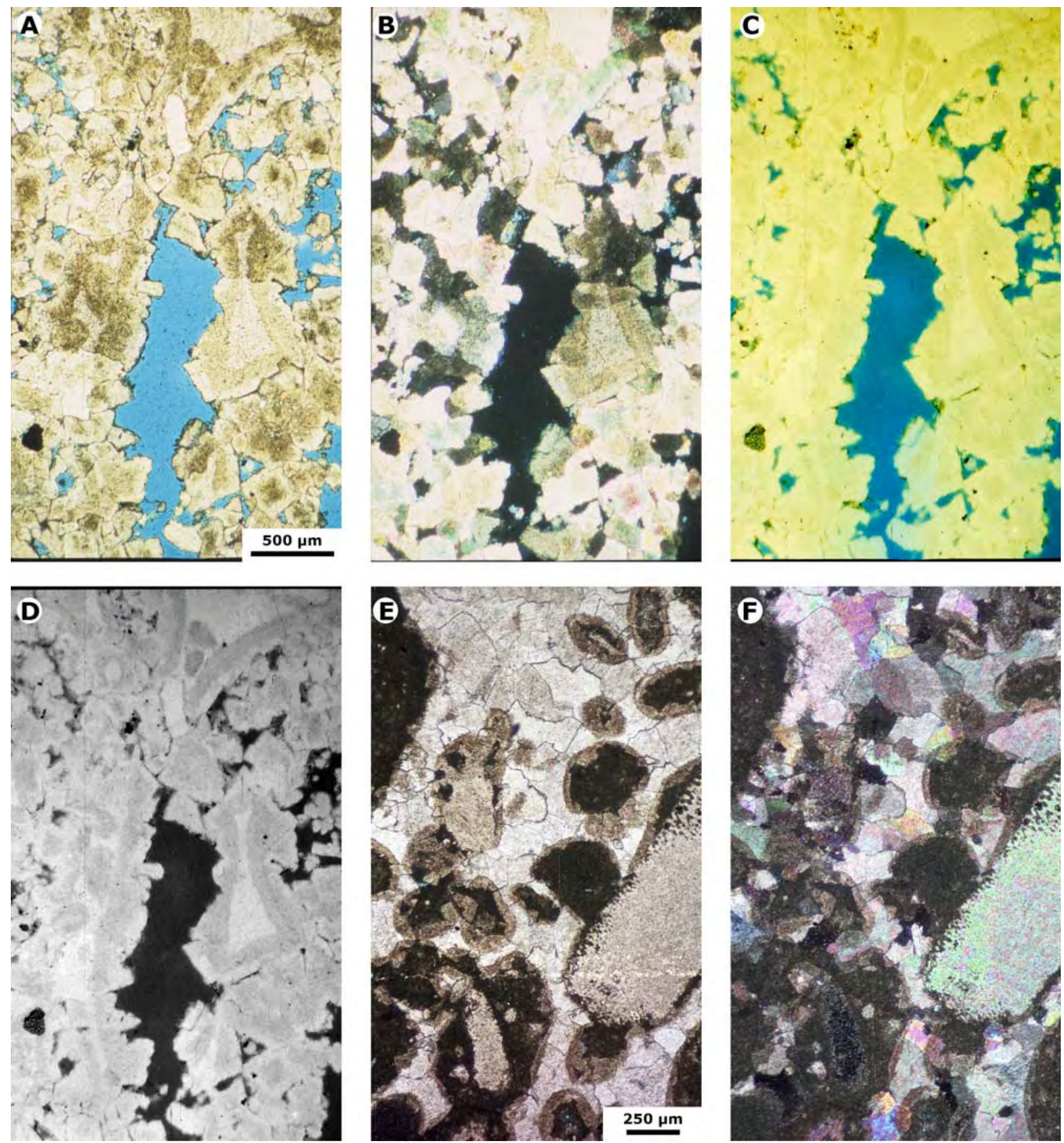

Figure 4: Pinda Group. A-D) Dolograinstone with some leaching vugs: A) TL transmitted light; B) PL polarized light (analyzed); C) RL reflected light; D) ERL enhanced reflected light. E-F) Partly dolomitized grainstone. The micritic ooid cortexes and the echinodermic remains are not dolomitized, nor leached: E) TL transmitted light; F) PL polarized light (analyzed). For confidentiality purposes the sample depths and the name of wells are not provided.

light within the replacing dolomite crystals (Figs. 3.A, 4.A, 5. F), but it is not always clear (Fig. 4.EF) whether intergranular space is filled with a dolomitic cement occluding an original intergranular pore or with a dolomitic replacement after an original calcitic cement.

The next step is the proper identification of the paragenetic sequence, i.e., the sequence of discrete diagenetic events, which is usually displayed either along a scale of relative time (commonly opposing "early" -i.e., near-surface diage- nesis- and "late" -i.e., burial diagenesis-) or, in the best cases only, along a chronostratigraphic scale (e.g., Granier, 1994; Granier \& STAFFELBACH, 2009). At this stage of the workflow cathodoluminescence $(\mathrm{CL})$ microscopy may reveal some hidden details (see § 5.) as, for instance, zoning that is the signature of changes in the composition of the brines. Such magnified and coloured CL views are the cornerstones of cement stratigraphy. 

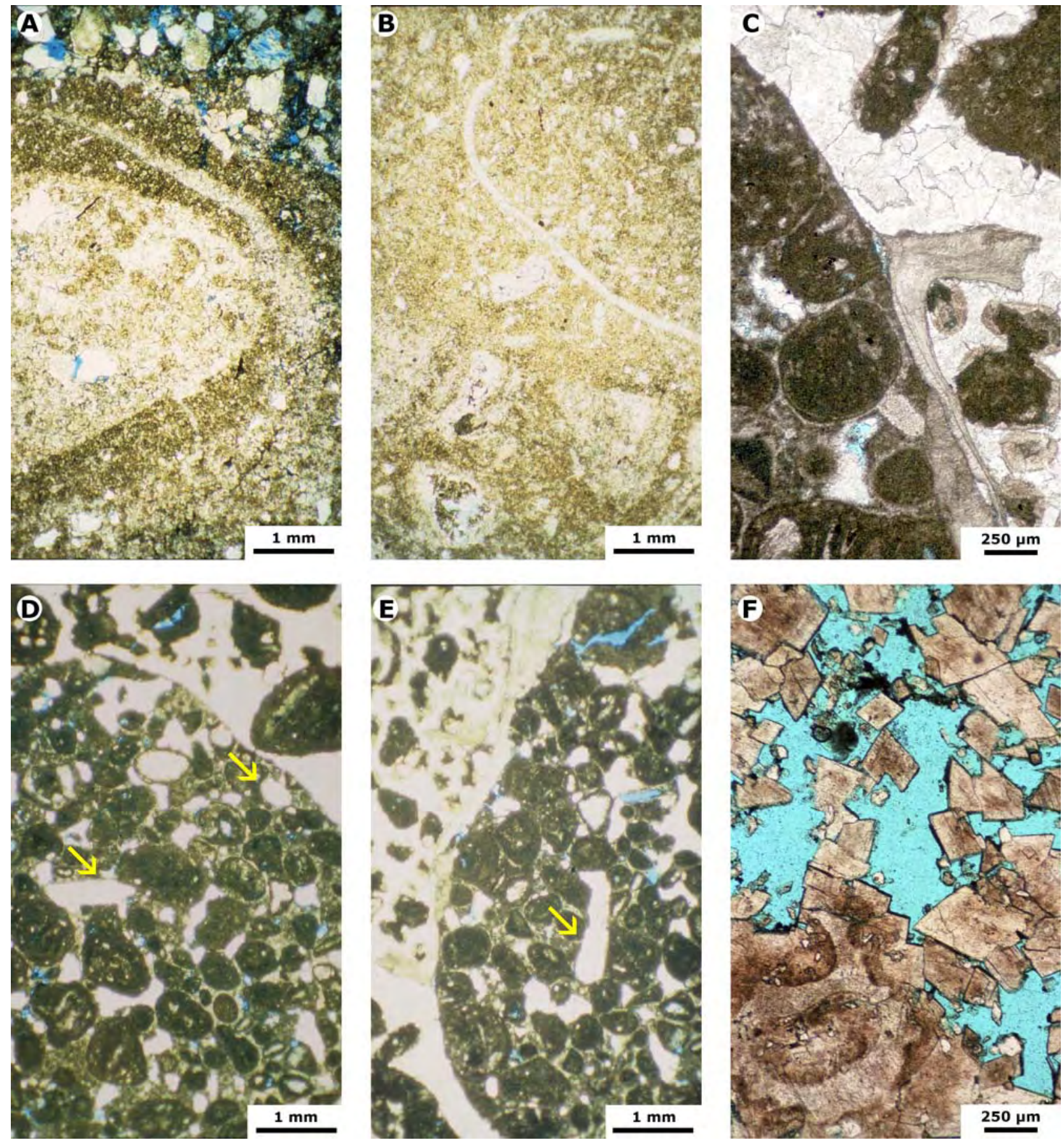

Figure 5: Pinda Group. A) Macroboring with borer shell. B) Macroboring with borer shell in a dolowackestone. C) Oyster shell encrusting a pebble. Grains are dolomitized at their edges. D) Mesoborings (yellow arrows) in a pebble. E) Mesoboring (yellow arrow) in an encrusted pebble. F) Replacement dolomite after an aragonitic gastropod shell. All photos in transmitted light (TL). For confidentiality purposes the sample depths and the name of wells are not provided.

In the Pinda Group case, there are very few identifiable features to build on. Early cementation (see § 4.), compaction (first mechanical and later chemical compaction, see $\S 6$.), replacement, leaching (see $\S$ 7.), late cementation, fracturing, and the hydrocarbon reservoir charge are either diachronous from one structure to the next or poorly time-constrained events. Therefore the time scale used herein is relative time at the scale of individual structures.

\section{Early cementation in the Pinda Group}

The "pervasive" dolomitization has wiped out almost all evidences of early cementation. Locally, very few are still preserved: 

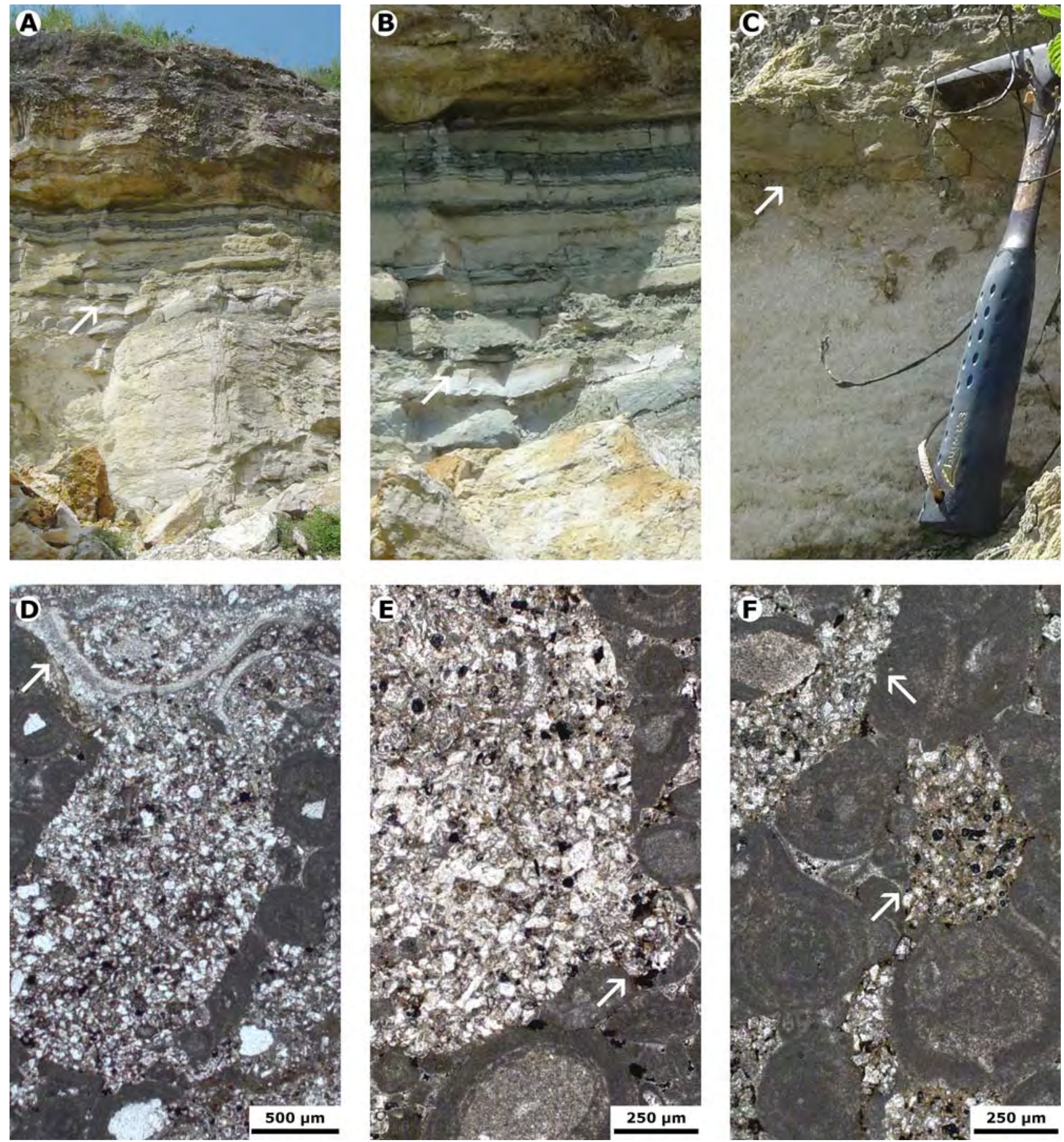

Figure 6: A-B) Quarry section near Areia Branca. Arrows point to the hardground at top of the oolitic unit. C) Hardground (arrow). D-F) Borings in transmitted light (TL): D) macroboring and encruster (arrow); E) mesoboring (arrow) and macroboring; F) mesoborings.

1. Few pebble-sized intraclasts in a partly dolomitized, oolitic grainstone. They are encrusted (by oysters: Fig. 5.C ; GRANIER, 2017, PI. 1, fig. 9) and bored, both features are the mark of early lithification. The mesoborings (Fig. 5.D-E ; GRANIER, 2014) are ascribed to Trypanites ichnosp. (Granier, 2017, PI. 7, figs. 12, 15);

2. Macroborings in a fully dolomitized facies. Where the borer shell is still in situ, cf. Lithophaga spp. (Fig. 5.A-B ; GRANIER, 2017, PI. 5 , figs. 4-5), these macroborings are ascribed to Gastrochaenolites ichnosp.
Such features are rarely observed, even in the field. The author did not get the opportunity to do field work in Angola, but Brazil offers some outcrop analogs. For instance, in a quarry $\left(10^{\circ} 46^{\prime}\right.$ 42.8"S $\left.37^{\circ} 15^{\prime} 38.2^{\prime \prime} \mathrm{W}\right)$ near Areia Branca, some $30 \mathrm{~km} \mathrm{NW}$ of Aracaju in the Sergipe basin, together with Dimas DIAS-BRITO and Mitsuru ARAl, we identified a bored hardground capping a slightly dolomitized, oolitic limestone unit within the Riachuelo Formation (Fig. 6). 

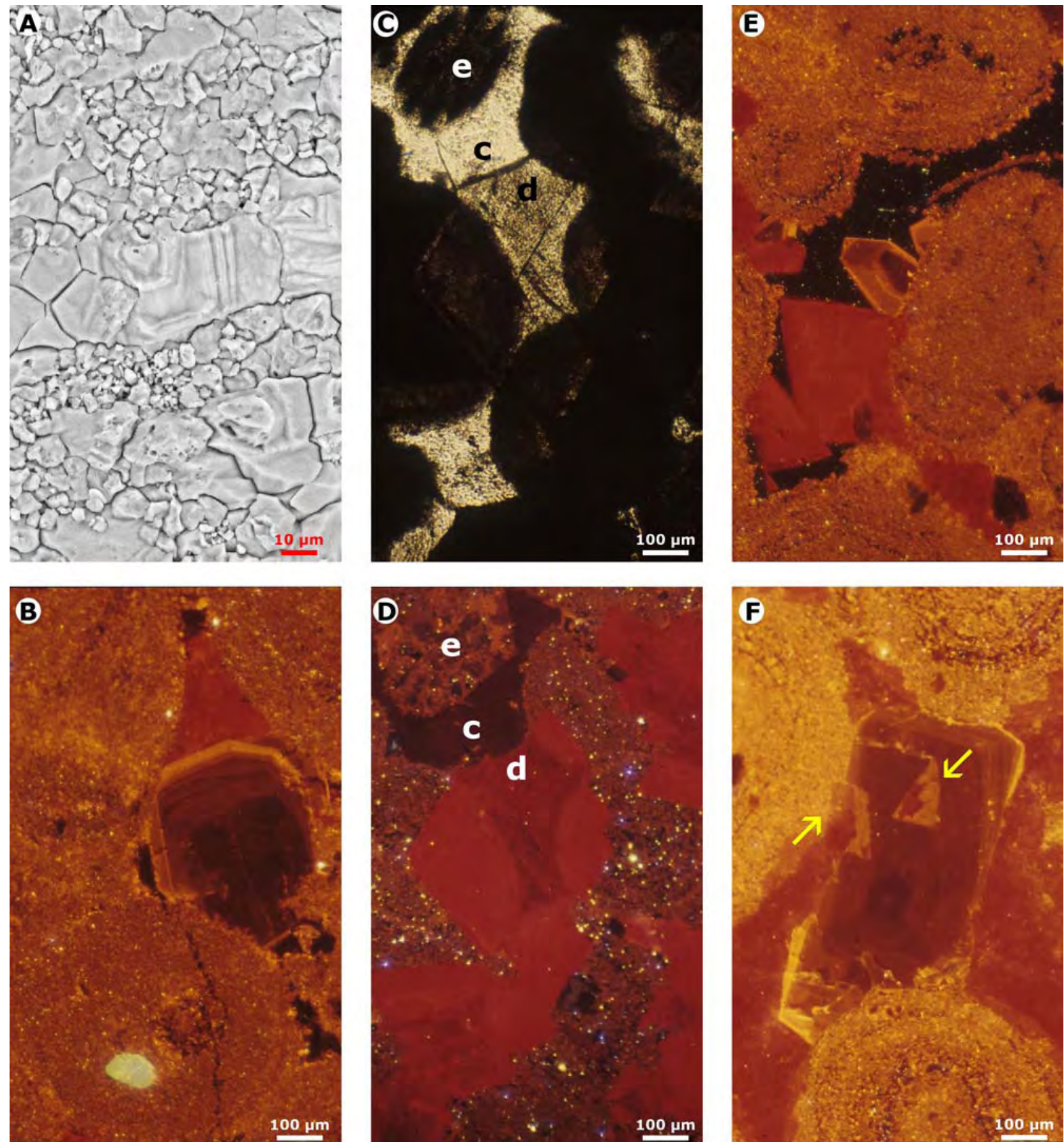

Figure 7: A) Dissolution zoning of calcite cement on a polished, then slightly etched surface, SEM (Brazilian material). B-F) Pinda Group. B) Slightly dolomitic oolitic grainstone. Here a large dolomite crystal in red color (at the top) is located in an intergranular cement position. The large calcite crystal (in the center) is zoned with a first thick zone dark brown in color, then light brown and orange luminescent zones. This single crystal probably grew on an echinoderm bioclast. This calcite cementation preceded dolomite cementation. C-D) Slightly dolomitized oolitic grainstone with an echinoid spine (e) and its calcite rim cement (c). It is not clear whether all dolomite is replacement only, or replacement and cement (d): C) TL transmitted light; D) CL cathodoluminescence. E-F) cathodoluminescent views of slightly dolomitic oolitic grainstones: E) one zoned calcite crystal is corroded by red dolomite (arrow); F) the large zoned calcite crystal that probably grew on an echinoderm bioclast is partly replaced by dolomite as evidenced here by two rhombic shapes (arrows). For confidentiality purposes the sample depths and the name of wells are not provided.

\section{Essentials of cement stratigraphy (using cathodoluminescence)}

Cement stratigraphy, which is one essential component of the paragenetic sequence, requires a search for the larger crystals. A skilled petro- grapher will first look for echinoderm remains and then focus on their syntaxial cements because such rims are usually "much wider than" any crystal "formed on the surface of other kinds of grain" (GRANIER \& STAFFELBACH, 2009). 
The skeletal elements of echinoderms have a monocrystalline optical behaviour (e.g., LUCIA, 1962; EVAMY \& SHEARMAN, 1965, 1969; TOWE, 1967), although they were made of polycrystalline aggregates that promptly recrystallized in their original organic framework (TowE, 1967). As pointed out by Granier and STAFFELBACH (2009), owing to this monocrystalline behaviour, "they are capable of acting as "germs" for calcite cementation. (...) The syntaxial cements developed around these echinodermic bioclasts register in detail all the phases of cementation that affected" the rock. These details are made visible by cathodoluminescence $(C L)$ microscopy, which reveals the occurrence of color zoning (Fig. 7.B, E-F) related to trace elements such as $\mathrm{Mg}$, Fe and $\mathrm{Mn}$.

It is assumed that the larger zoned crystals (Fig. 7.B, F) should be syntaxial overgrowths on echinoderm remains. Because most calcitic cementation stopped when dolomitic replacement started (due to huge changes in the composition of the brines), calcitic syntaxial overgrowths predate dolomitic replacement. Thus, the boundary of replacement dolomite and calcite crystals is locally jagged (Fig. 7.F), or some dolomite rhombs crosscut or look like they are superimposed on calcite crystals (Fig. 7.F), i.e., they make it clear that dolomitic replacement postdates calcitic cementation.

Incidentally, on the basis of crystal growth and morphology, one should question the dolomitic nature of the zoned "limpid epitaxic cement" illustrated by EICHENSEER et al. (1999: Fig. 16). It could well prove to be another example of calcitic syntaxial overgrowth on echinoderm remains. Unfortunately the author cannot get access to this proprietary material to validate this statement.

\section{Essentials of compaction}

The behaviour of a calcareous sediment, more specifically the grain-dominated fabrics (i.e., in the reservoir units), with respect to compaction should significantly vary depending on whether the sediment remains unconsolidated, whether it is cemented early (see $\S 4$.), or whether it suffers more porosity-reducing cementation.

In a case of the loose calcareous grains documented by NicolAIDES and WALLACE (1997), when the sedimentary pile reaches some $150 \mathrm{~m}$, compaction, which is first mechanical, consists of grain rearrangements, eventually grain breakage, and subordinate intergranular porosity reduction. When the sedimentary pile exceeds $400 \mathrm{~m}$, then compaction becomes chemical. Dissolution is first located at "sutured" grain contacts and a limited subordinate calcitic cementation may occur, also contributing to porosity reduction. With increasing depth "fitted-fabrics and microstylolites" are found. According to NICOLAIDES and WALLACE (1997), these features are "well-developed (...) between 430 and $550 \mathrm{~m}$ " in the material they studied. On the basis of rather limited set of information, they reported that genuine stratiform stylolites visible to the naked eye as opposed to microstylolites that require a microscope to be seen, "are totally absent to depths of approximately $670 \mathrm{~m}$ ". As a matter of fact, pressure-solution features may occur at lesser depths in earlycemented grain-dominated fabrics than in unconsolidated ones. The amount of early cementation, with dominant precipitation of low-Mg calcite in unconfined (phreatic) continental groundwaters and of high-Mg calcite or aragonite in unconfined (phreatic) marine groundwaters, could play a key role in the relative timing of chemical compaction.

In contrast, in mud-dominated fabrics (i.e., in the non-reservoir, overburden units), pressuresolution features occur at lesser depths. For example, still according to NICOLAIDES and WALLACE (1997), "dissolution seams are observed at depths as shallow as 190 m", but "they appear to be better developed in the clay-rich portions of samples buried at depths of $340 \mathrm{~m}$ or deeper". Note that because the rates of sedimentation and of mechanical compaction differ significantly in grain-supported and mud-supported fabrics the same depth of their respective sedimentary piles should represent significantly different durations.

To the author's knowledge, there are few localities with fully-cored drilling in shallow-water carbonates on passive margins. The present author had once the opportunity to study a full set of thin sections from DSDP site 392A (BENSON et al., 1978) drilled off the southeastern United States coast at a water depth of $2600 \mathrm{~m}$. This core cuts through almost $100 \mathrm{~m}$ of nannofossil ooze and clays overlying more than $200 \mathrm{~m}$ of uppermost Jurassic (sensu OPPEL, i.e., including the Berriasian) shallow-water carbonates (FouRCADE \& GRANIER, 1989). In this more than $300 \mathrm{~m}$ thick section, the absence of any pressure solution feature, either in grain-dominated (commonly partly cemented) or mud-dominated fabrics, is striking. This fact is broadly corroborated by the observations of NICOLAIDES and WALLACE (1997).

Last but not least, because dolomite has a lower pressure solubility than calcite, rhombs are commonly found concentrated at the boundaries of stylolites or as part of the insoluble material (RAILSBACK, 2002, Fig. 3.8). For instance, in the sample of Figure 12.G, which is a slightly dolomitized wackestone with planktonic foraminifers, few dissolution seams are observed with some dolomite rhombs concentrated at these specific levels. Accordingly in this mud-dominated, nonreservoir facies the limited dolomitic replacement predates the seams. However, in former graindominated reservoir facies, it looks like dolomitic replacement wiped out preexisting solution seams (Fig. 8.A-D). That could explain the scarcity of stylolites in dolomitic intervals; alternatively the latter may be also due to the relative inherent resistance to solubility of dolomitized intervals. 

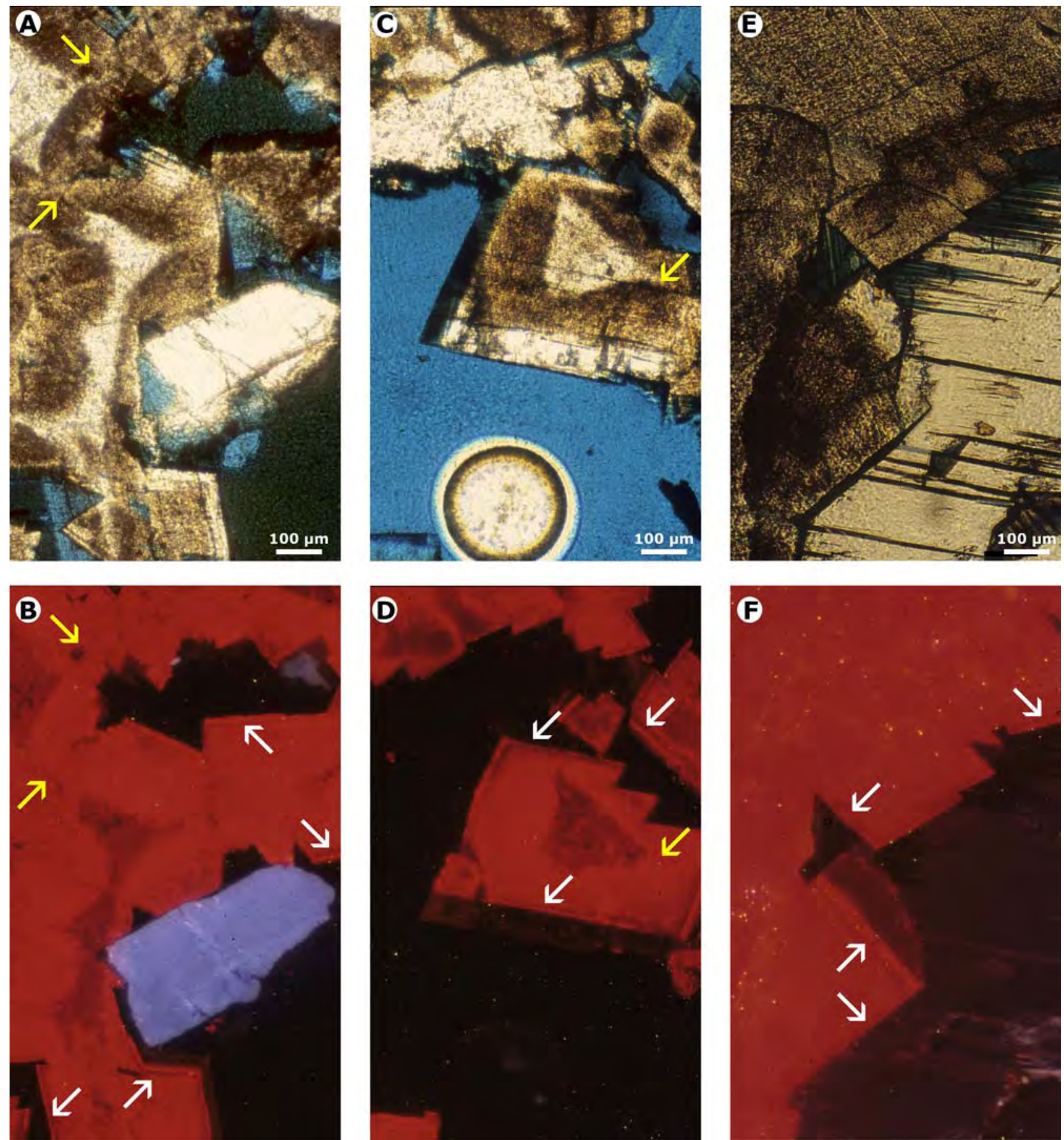

Figure 8: Pinda Group. A-F) Yellow arrows: "sutured" grain contacts; white arrows: outer zoning in dolomite crystals, i.e., dolomite overgrowths (? replacement, then cement). A, C, E) TL transmitted light; B, D, F) CL cathodoluminescence. A-D) Porous dolograinstone, with porosity resulting from the late leaching of the undolomitized core of the former calcareous grains. In B), a feldspar grain appears in blue color. E-F) Dolograinstone with leaching vugs cemented by late anhydrite. For confidentiality purposes the sample depths and the name of wells are not provided.

To summarize, although there is no absolute depth scale for compaction, either mechanical or chemical, one can always deal with the few available data and a relative depth scale to calibrate any paragenetic sequence.

Note: Stratiform stylolites are not restricted to limestones and dolomites. Very good examples are in quartzites of the Devonian "Grès armoricain" at Pointe de Pen Hir $\left(48^{\circ} 16^{\prime} 03.1^{\prime \prime N} 4^{\circ} 36\right.$ 57.1"W), near Camaret in Brittany, France (Fig.
9). There, stylolites definitely required much deeper burial to develop than in limestones. GRATIER et al. (2005) who produced "experimental microstylolites in quartz" pointed out the effects not only of obvious determining factors such as pressure and temperature, but also those of the nature of the brine and the duration. These authors successfully produced microstylolites in quartz grains under a vertical uniaxial stress of $200 \mathrm{MPa}$, with a silica solution pressure of $150 \mathrm{MPa}$, i.e., 

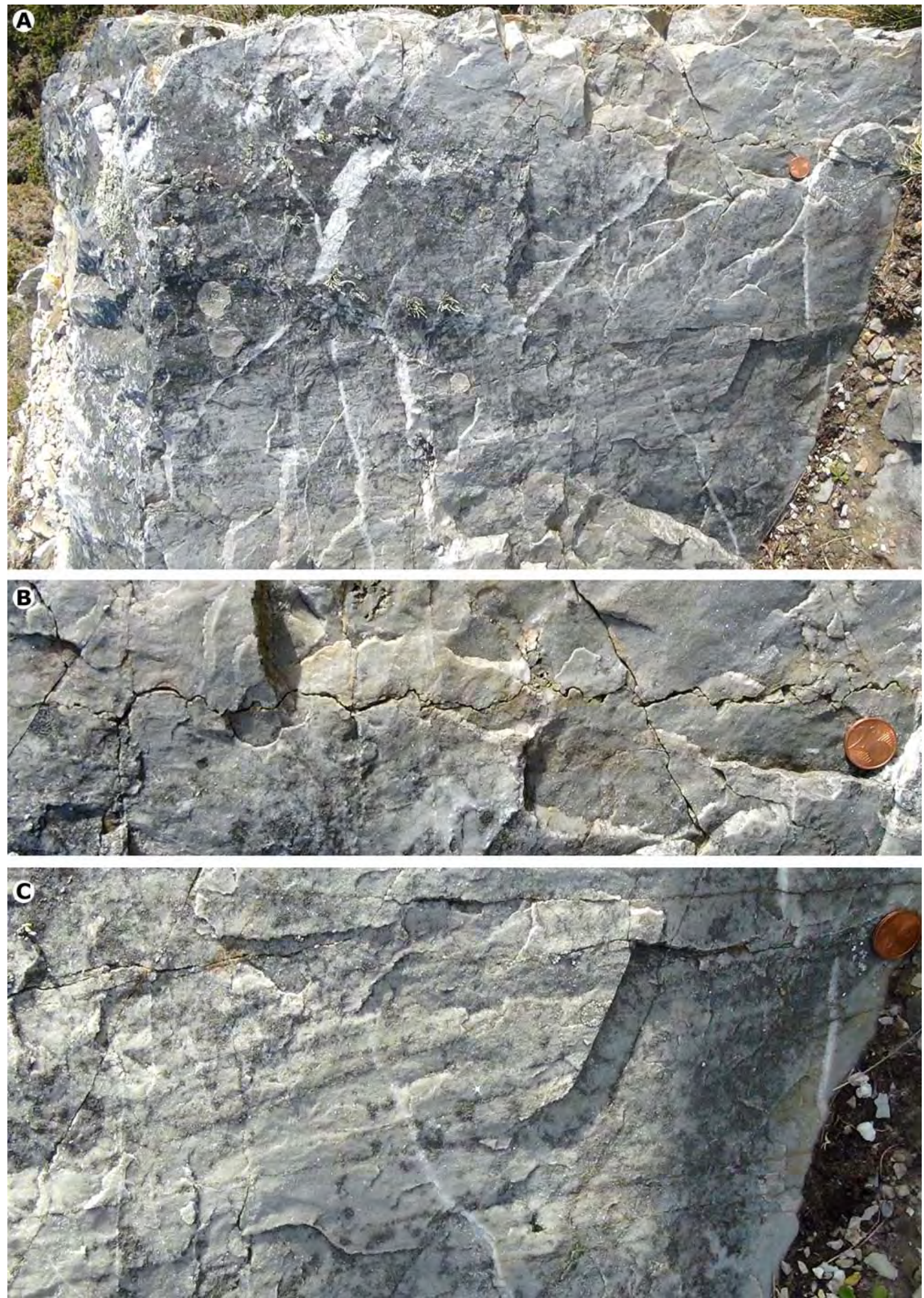

Figure 9: A-C) Stylolites in quartzites of the Devonian "Grès armoricain" at Pointe de Pen Hir, near Camaret in Brittany (France): B) detail of a macrostylolite; C) mesostylolites highlighting the low-angle oblique lamination. Scale: the 2 cents coin is $1.8 \mathrm{~cm}$ in diameter. 
with a differential stress of $50 \mathrm{MPa}$, and at a temperature of $350^{\circ} \mathrm{C}$. Experiments by ZHANG et al. (2010) on "wet granular calcite" required lesser stresses (20 to $47 \mathrm{MPa}$ ) and temperatures (28 to $150^{\circ} \mathrm{C}$ ). In conclusion, these experiments suggest that the burial of the "Grès armoricain" in western Brittany should not be estimated at hundreds of meters as for the Pinda limestones and dolomites, but in kilometres.

\section{Essentials of carbonate leaching}

Artificial leaching provides information on natural leaching. For instance, preparation of SEM samples requires first polishing of the rock surface and then etching it to visualize some features. A polished limestone sample from the Riachuelo Formation collected near Areia Branca, some 30 $\mathrm{km} \mathrm{NW}$ of Aracaju, Brazil, was lightly etched in a less than $10 \%$ aqueous solution of hydrochloric acid for not more than 20 seconds. Under the SEM the larger calcite crystals display zoned scours and grooves (Fig. 7.A). This dissolution zoning, which is similar to the color zoning observed in cathodoluminescence views, probably results from slight variations in the mol\% of trace elements, notably in the magnesium content. Accordingly, the scours possibly correspond to high-Mg calcite (HMC), i.e., calcite with a magnesium content greater than 8-12 mol\%, and the groves to low-Mg calcite (LMC), i.e., calcite with a magnesium content less than $8 \mathrm{~mol} \%$.

However, whereas LMC is the most stable polymorph of calcium carbonate and HMC is even more soluble than aragonite, stating that LMC is more stable than aragonite that in turn is more stable than HMC may prove to be incorrect. As a matter of fact, there are several limitations to the leaching of some former $\mathrm{HMC}$, namely the biogenic HMC as opposed to the non-biogenic HMC (chemical cements):

1. For instance, modern rhodophyta with 10-30 mol\% of $\mathrm{MgCO}_{3}$ and echinoderms with 10-15 mol\% are rarely leached. A plausible explanation for this phenomenon is the occurrence of organic matter originally embedded in these biogenic calcite crystals that prevented or restricted dissolution (GRANIER, 2014; GRANIER et al., 2014);

2. Biogenic HMC often loses some $\mathrm{Mg}$ and is converted / "promptly recrystallised" / into the most stable LMC (TowE, 1967), a phenomenon which is still "not well understood" (FLÜGEL, 2004) but that would prevent later dissolution;

3. Skeletal elements of echinoderms look like they are strongly resistant to leaching because calcite crystals resulting from the combination of an echinoderm nucleus and its overgrowth are commonly the largest crystals in a thin section. Crystal size may be another limiting factor;

4. Further on the subject of echinoderm remains, according to GRANIER and STAFFELBACH (2009), "Syntaxial cements developed at their peripheries are much wider than those formed on the surface of other kinds of grain". Owing to their thickness and continuity these LMC overgrowths may contribute to the preservation of the former HMC echinoderm cores.

Dissolution may also affect some dolomite crystals. Similar to calcite with LMC versus HMC, two dolomite types can be differentiated on the basis of their calcium content: low-Ca dolomite (LCD), i.e., dolomite with a calcium content lower than 55 mol\%, versus high-Ca dolomite (HCD). As reported by JONES (2007), LCD is more stable than HCD. Hollow (Fig. 10.A-B, D) or "Russiandoll" (Fig. 10.E) rhombic crystals are regarded as the result of differential dissolution of HCD compared to LCD. As documented here (Fig. 10.C-D), such small crystals commonly occur as replacement of the inner part of micritic allochems next to larger crystals replacing their outer part.

Leaching of hollow dolomite rhombic crystals (Fig. 10.A-B, D) and that of some calcitic remains (Fig. 10.C) are probably coeval (note that Fig. 10.D is a detail of Fig. 10.C). In some other cases (e.g., Fig. 10.F), cathodoluminescence analyses eventually reveal inside-out dolomite sensu J ONES (2007) that may suggest a story more complex than originally thought.

\section{More petrographic observations of some Pinda thin sections}

In the original data set, former grain-supported textures are better documented, probably because they correspond to cored intervals in the best reservoir zones and they captured more attention of the $O \& G$ practical petrographers.

\section{ECHI NODERM REMAI NS AND SYNTAXI AL OVERGROWTHS}

Echinoderm remains are definitely the most remarkable bioclasts (see $\S 5$.). Both echinoderm remains and their syntaxial cements are visible in many poorly dolomitized samples (Figs. 4.E-F, 7.C-D) as well as in fully dolomitized samples (Fig. 11.A-F):

- The sample in Figure 4.E-F has a grain-supported texture. It is an oolitic grainstone, partly dolomitized, with micritic ooids. The echinoderm remains, some of which are coated, did not undergo much dolomitization, i.e., replacement which is restricted to the periphery of the grains, without excluding possible cementation in the original intergranular pores; 

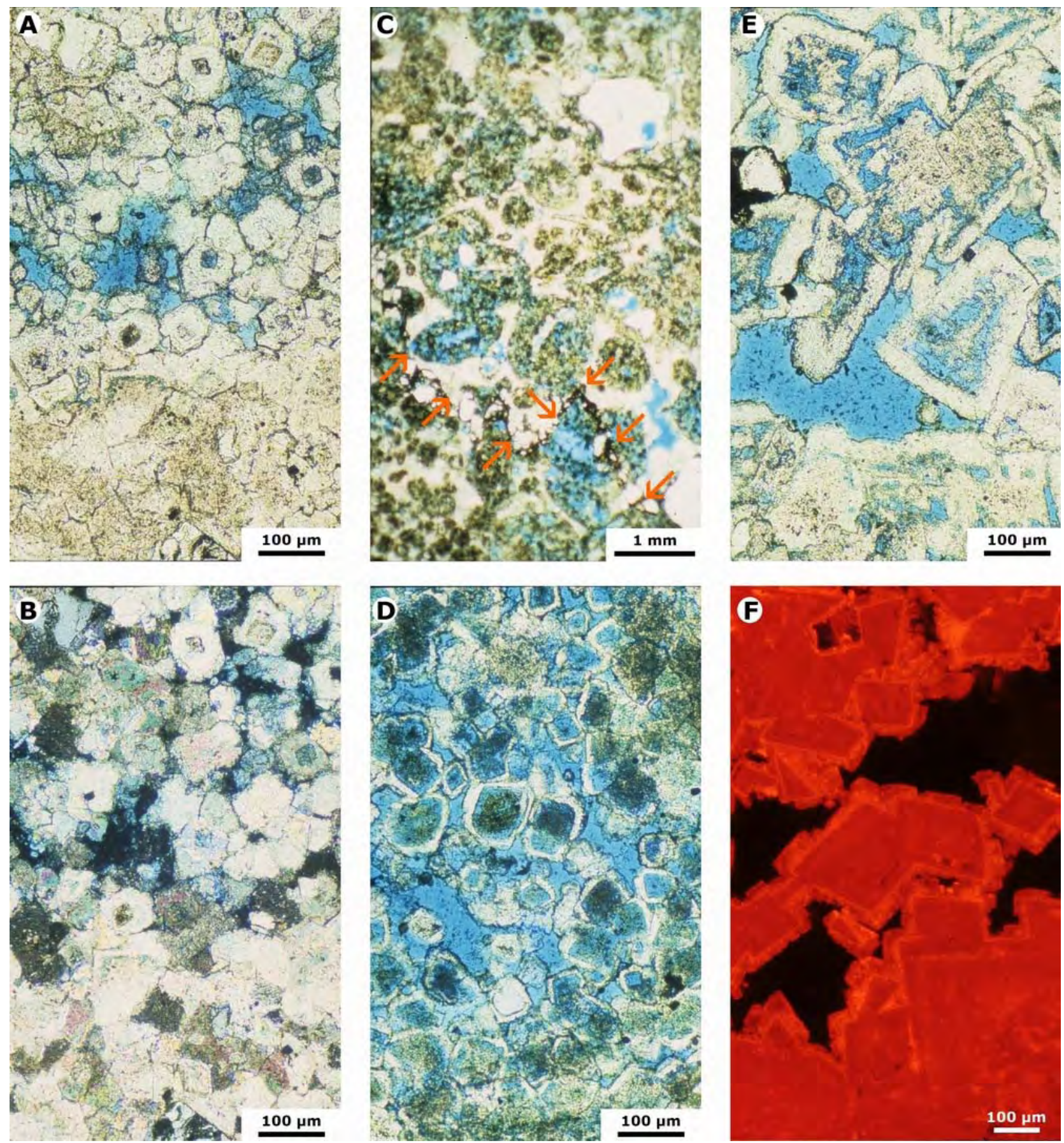

Figure 10: Pinda Group. A-B) Hollow dolomite rhombic crystals: A) TL transmitted light; B) PL polarized light (analyzed). C-D) Oolitic dolograinstone, TL transmitted light: C) red arrows point to a stylolite evidenced by insoluble impurities and small quartz grains; D) detail of the previous image with hollow dolomite rhombic crystals within the original allochems. E) "Russian-doll" dolomite rhombic crystals, TL transmitted light. F) Possible inside-out dolomite sensu J ONES (2007), CL cathodoluminescence. For confidentiality purposes the sample depths and the name of wells are not provided.

- The sample in Figure 4.C-D is a slightly dolomitized oolitic grainstone. Here the calcite rim cement of the echinoid spine was apparently not affected by "dolomitization" and it is not clear whether all dolomite is replacement only, or replacement and cement;

- The sample in Figure 11.A-D has also a grainsupported texture, but this grainstone was fully dolomitized as indicated by the entirely red-coloured cathodoluminescence. An echinoid spine (fully dolomitized) covers one-third of the photo. It has kept its monocrystalline behavior even after the original calcite was replaced by dolomite. The original syntaxial rim cement surrounding it is still visible and predates dolomitization; 

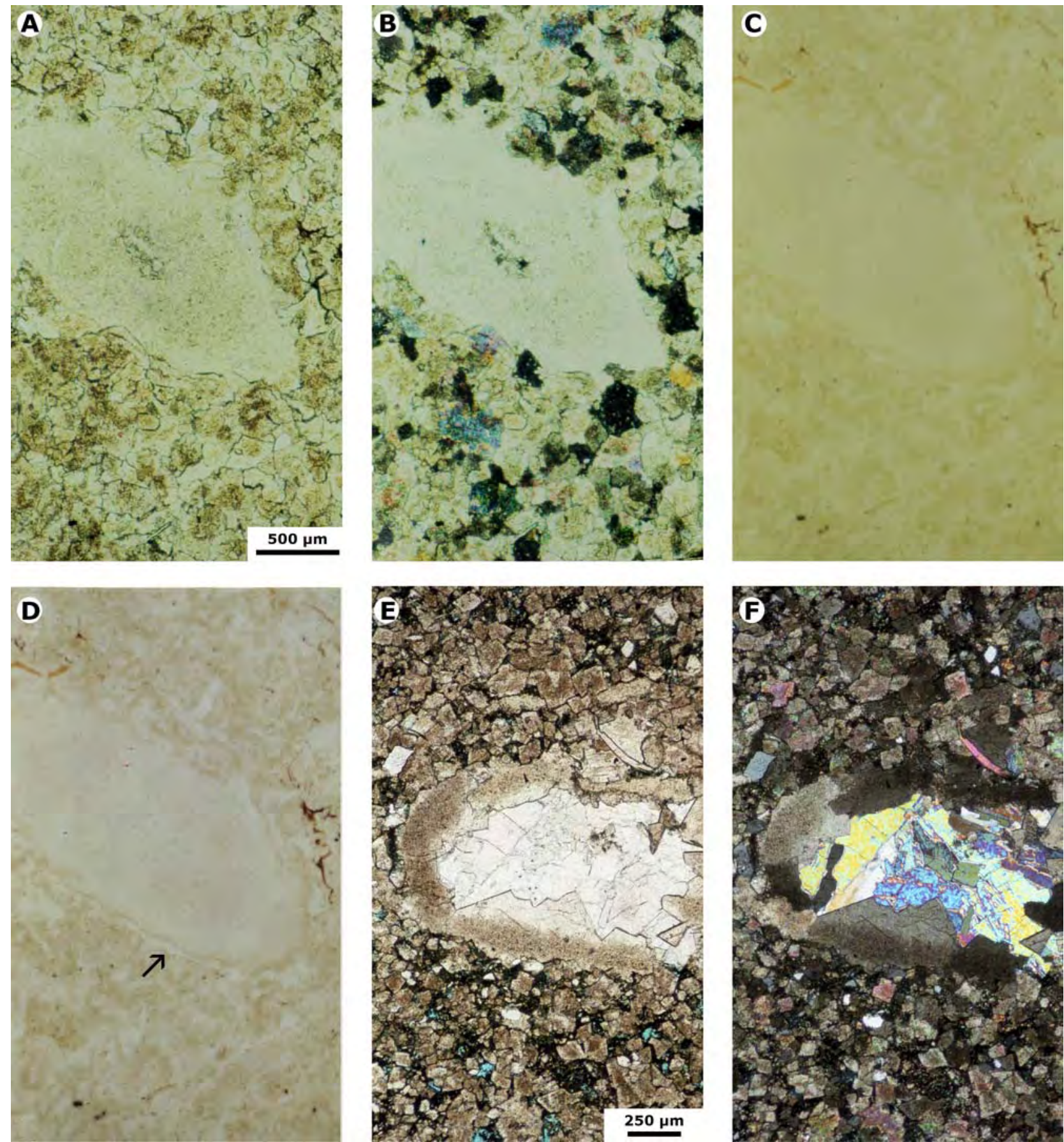

Figure 11: Pinda Group. A-D) Dolograinstone with a large echinoid spine: A) TL transmitted light; B) PL polarized light (analyzed); C-D) ERL enhanced reflected light. E-F) Dolograinstone with an echinoid theca : E) TL transmitted light; F) PL polarized light (analyzed). For confidentiality purposes the sample depths and the name of wells are not provided.

- The sample in Figure 11.E-F is also a dolograinstone. An echinoid theca covers one third of the photo. Individual pieces constituting the theca have a monocrystalline behavior. Here again they were dolomitized and have developed syntaxial cement on the inner side of the empty thecal cavity. However, shapes of these syntaxial crystals bear the morphological signature of dolomite. Therefore, part of the echinoderm syntaxial rim cement is here related to the dolomitization process. The remaining space of the thecal cavity was later occluded by anhydrite.

\section{Chemi Cal compaction}

The sample in Figure 3 is a fully dolomitized grainstone. Ghost of the grains are visible in both transmitted light ( $T L)$ and reflected light $(R L)$; these sub-rounded allochems are poorly sorted. Shapes of the coarse replacement dolomite crystals are visible in both transmitted light (TL) and polarized light (PL). In addition, in this case, 

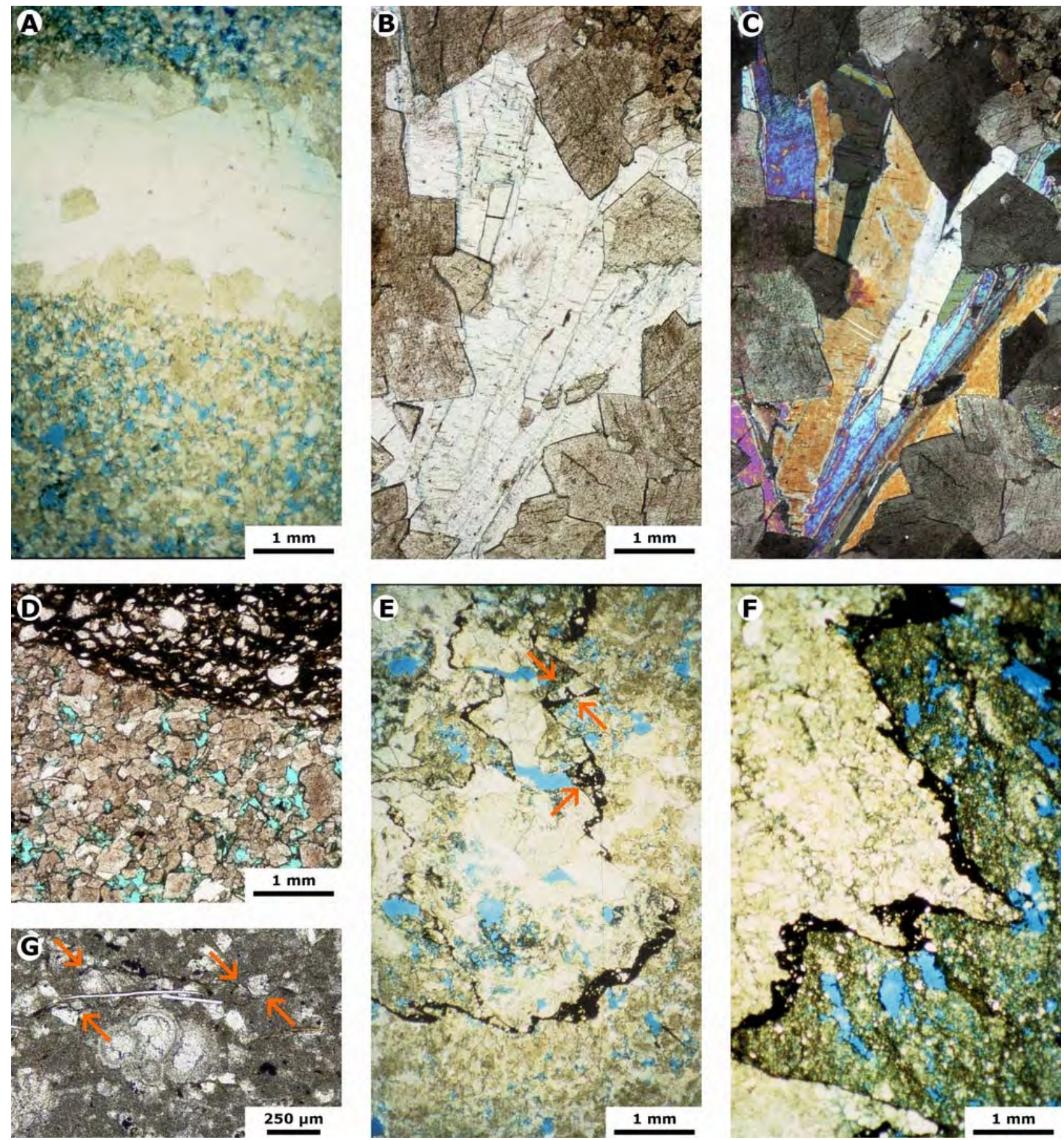

Figure 12: Pinda Group. A) Fracture cemented by baroque dolomite and anhydrite in a porous doloscrystalstone. The "intercrystalline" porosity results from the leaching of formerly undolomitized parts. It is the latest event in the sequence dolomitic replacement, fracturing, cementation with baroque dolomite, anhydritic cementation, and leaching. B-C) Cementation of a large cavity with baroque dolomite first and anhydrite second. D) Thick stylolitic contact with a porous dolograinstone. The "intercrystalline" porosity results from the leaching of formerly undolomitized parts. It postdates the stylolite. E) Thin stylolitic contact between two porous dolograinstones. Some dolomite rhombs (red arrows) are found at the contact and may well predate the stylolite. F) Thicker stylolitic contact between a porous dolowackestone and a tight doloscrystalstone, cemented by anhydrite. Porosity in the dolowackestone results from a leaching phase postdating the stylolite. G) Slightly dolomitized wackestone with planktonic foraminifers. Red arrows point to dolomite rhombs at the contact of dissolution seams, predating them. A-B, D-F) TL transmitted light; C) PL polarized light (analyzed). For confidentiality purposes the sample depths and the name of wells are not provided.

the enhanced version of the reflected light photo (ERL) reveals broken grains, sutured grain contacts, and a larger fracture cutting through several grains. Broken grains (Fig. 3.E, red arrows) and sutured grain contacts (Fig. 3.E, black ar- rows) indicate burial compaction, mechanical and chemical, of a loose calcareous sand. The fracture (Fig. 3.E, yellow arrows) indicates some burial cementation and the conversion of the loose calcareous sand to a grainstone. Because the sutu- 

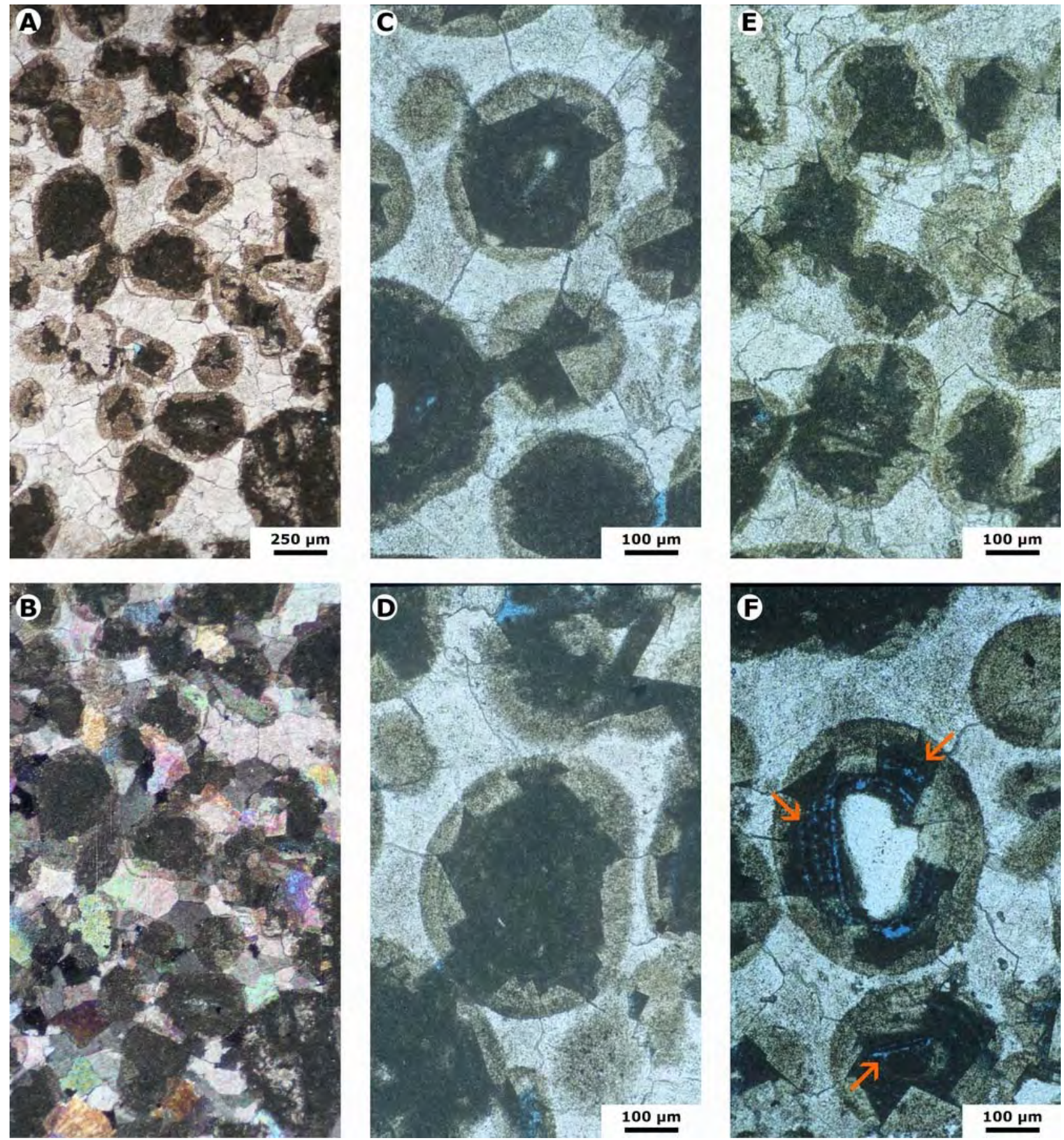

Figure 13: Pinda Group. A-D) Tight dolograinstone, partly dolomitized. Only the outer parts of calcareous grains are replaced by cloudy dolomite, the cores are not. It is not clear whether the rather hyaline dolomite between the allochems resulted from replacement only or it includes some cement. C-E) Some "intercrystalline porosity" can be detected. F) Red arrows point to limited leaching porosity within undolomitized grain cores. A, C-F) TL transmitted light; B) PL polarized light (analyzed). For confidentiality purposes the sample depths and the name of wells are not provided.

res of some grains, the breaks of individual grains, and those of the grainstone itself are locally embedded in large dolomite crystals, it is assumed that all these features predate dolomitic replacement.

The sample in Figure 4.A-D is similar to that of Figure 3. It is a fully dolomitized grainstone of very poorly sorted sub-rounded allochems and some vugs resulting from the dissolution of the undolomitized cores of the grains. In turn the sample in Figure 4.E-F is similar to that in Figure 4.A-D. The grains edges are dolomitized but, in this case, there is no porosity because the undolomitized cores of the grains were not leached. In both samples, grain sutures predate dolomitic replacement.

As already noted above, sutured grain contacts are commonly observed embedded in large dolomite crystals (Figs. 3.E, black arrows ; 8.A-D, yellow arrows). According to NICOLAIDES and WAL- 

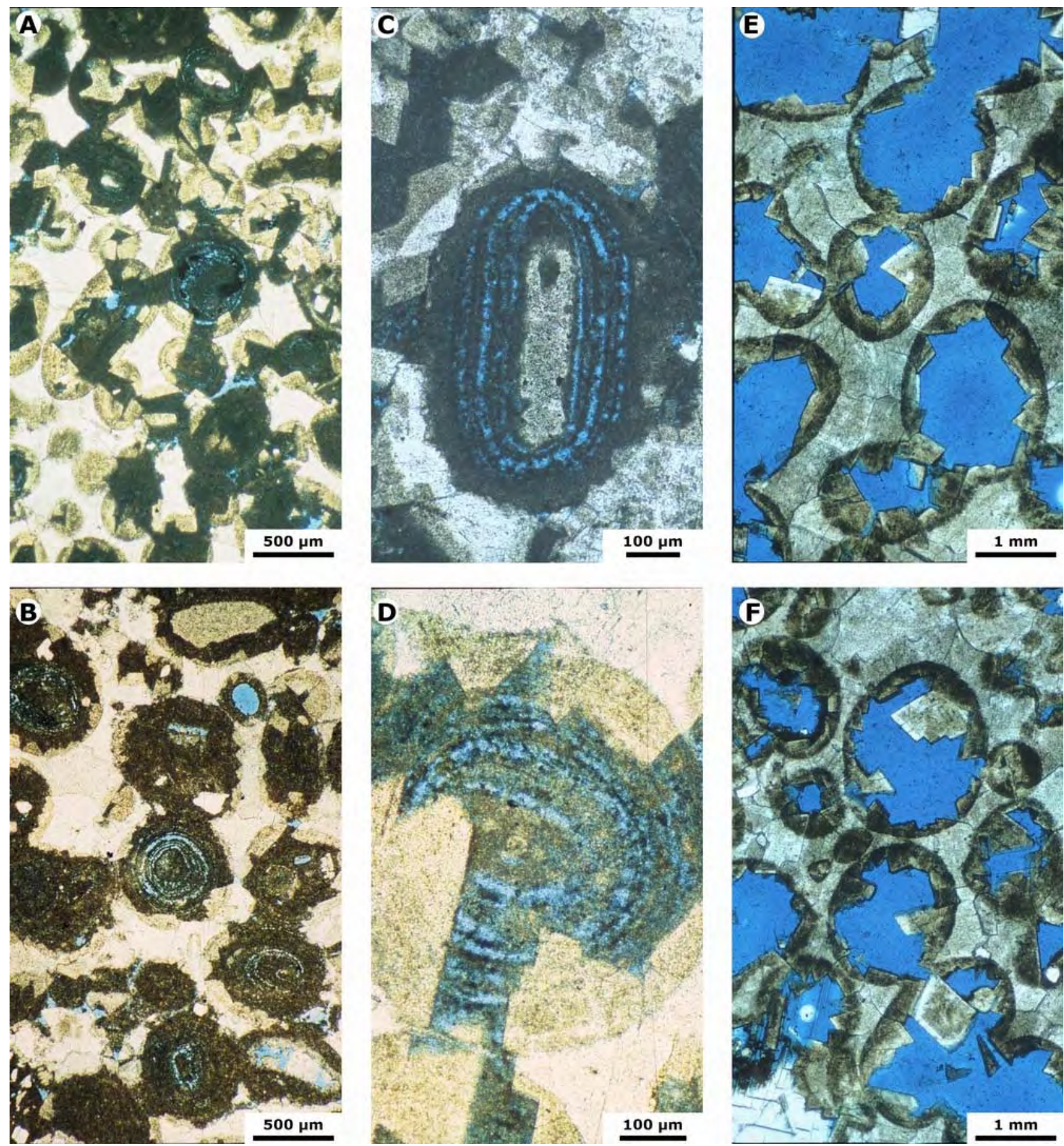

Figure 14: Pinda Group. A-D) Slightly porous dolograinstone, partly dolomitized. Only the outer parts of calcareous grains are replaced by cloudy dolomite, the cores are not. It is not clear whether the rather hyaline dolomite between the allochems results from replacement only or it includes some cement. The allochem cores, mostly ooids, are partly leached. E-F) "Fully" dolomitized porous dolograinstone. Porosity probably results from the complete leaching of undolomitized allochem cores in a former partly dolomitized tight dolograinstone. A-F) TL transmitted light. For confidentiality purposes the sample depths and the name of wells are not provided.

Figure 15: Pinda Group. The paragenetic sequence documented in the photomicrograph of Figure 12.A. The original mudstone was slightly dolomitized. Dolomitic rhombs, subequal in size and randomly arranged in the micritic matrix, resulted from replacement. The next step was fracturing that was later partly occluded by baroque dolomite. Two possible events occurred next: either 1 ) the remaining fracture porosity was cemented by anhydrite first, or 2) the remaining micritic matrix was leached first. Although this last hypothesis cannot be fully excluded (because anhydrite tends to precipitate in the larger pores), the first hypothesis is more sound. Accordingly, it is suggested that following baroque dolomite cementation anhydrite in turn cemented the fracture. Then the micritic matrix was leached generating final high porosity and permeability. Figure caption: Green: micrite (i.e., microcrystalline calcite); white/light grey: dolomite; blue: porosity; black: oil/bitumen. 

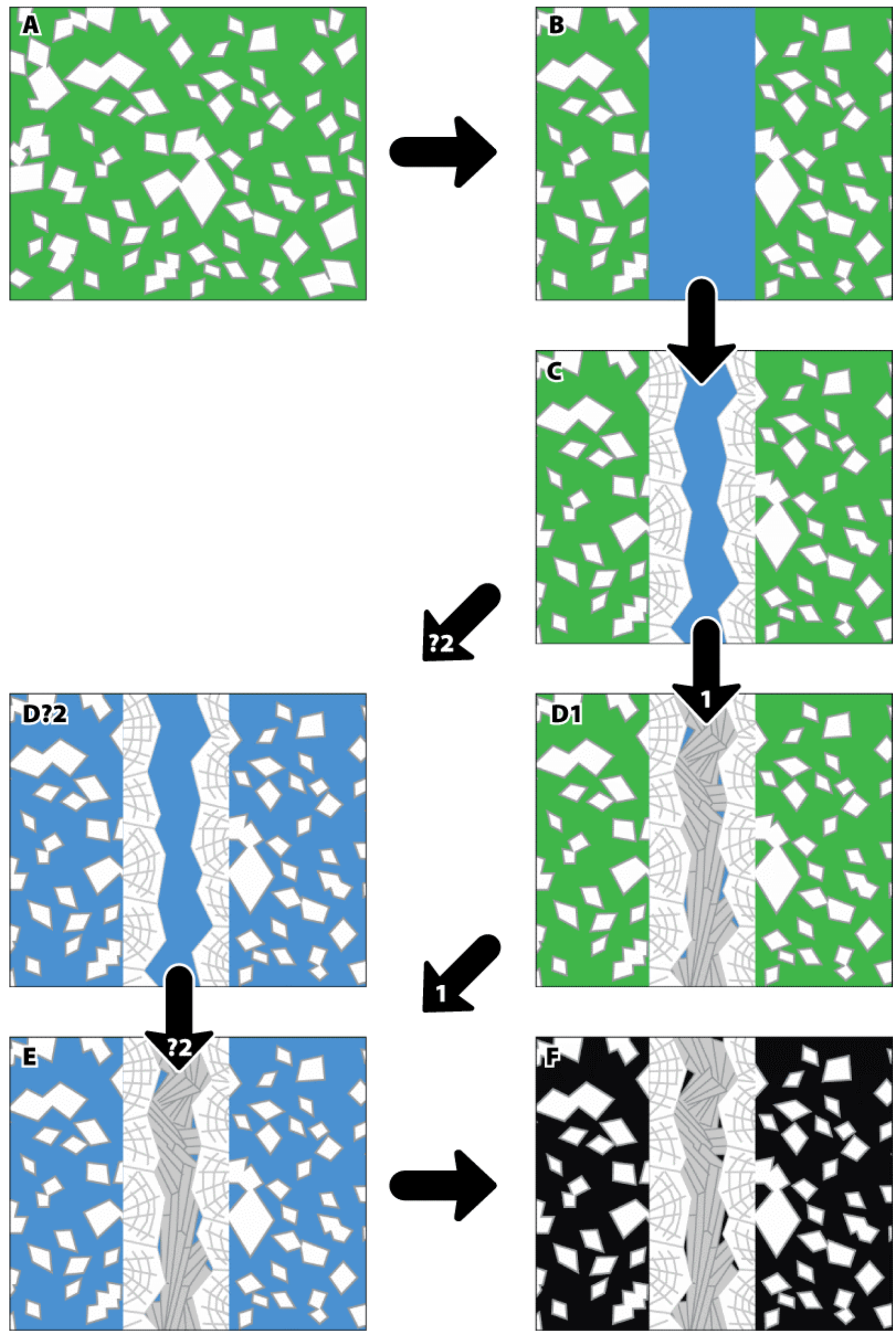

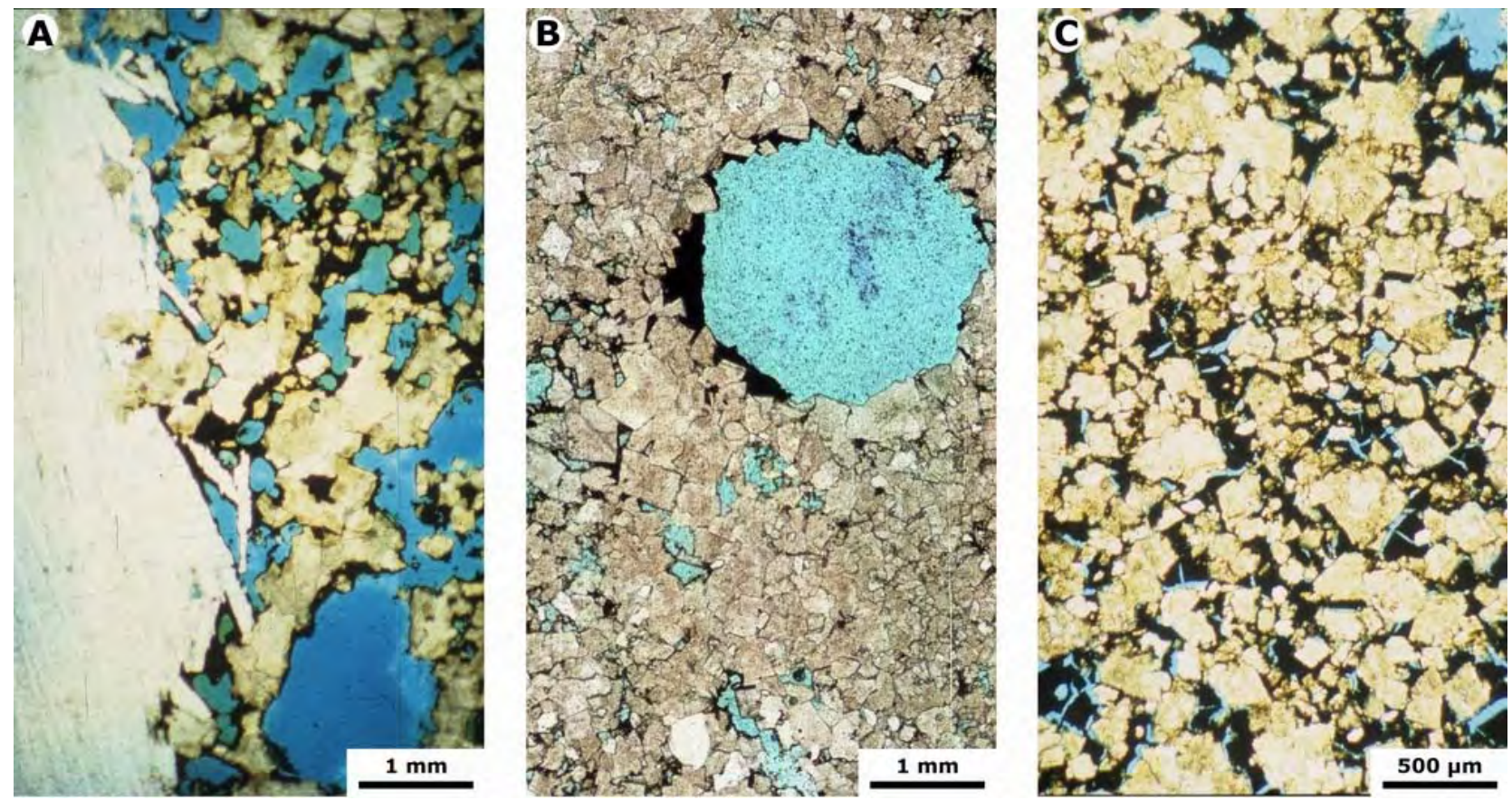

Figure 16: Pinda Group. A-C) Bitumen in "intercrystalline" and moldic porosity resulting from leaching. TL transmitted light. A) Porous dolograinstone. Anhydrite is located in the largest pores. B) Vuggy dolograinstone. C) "Intercrystalline" resulting from leaching in a dolograinstone. For confidentiality purposes the sample depths and the name of wells are not provided.

LACE (1997), this phenomenon indicates the initiation of chemical compaction, which occurs in grain-dominated fabrics at depths definitely exceeding $150 \mathrm{~m}$ and possibly $400 \mathrm{~m}$. In the examples of the Pinda Group carbonates, sutured grain contacts predate dolomitic replacement, suggesting that we are dealing with burial dolomitization.

Locally some small dolomite rhombs are in solution seams in muddy non-reservoir facies (Fig. 12.G) or in thin stylolites in grainy reservoir facies (Fig. 12.E). These small rhombs therefore partly predate these compaction features that are supposed to occur at different depths depending on the facies (see $\S 6$.). However, in other cases, it could be a matter of debate to determine whether some stratiform stylolites (Figs. 10.C, 12.DF) preceded, coincided, or followed this burial dolomitization stage. It cannot be excluded -but not definitively proven- here that the thickest stylolites in grainy reservoir facies (Fig. 12.D) may have started before initiation of the dolomitic replacement and that, once started, they may have continued during the replacement and even after.

\section{LEACHI NG}

In some cases, leaching happened later in the paragenetic sequence, and significantly contributed to porosity and permeability enhancement in formerly grain-dominated fabrics. Such facies (Fig. 3 - 4, 8, 11, 13 - 14.A-D) can be subdivided into a range of different subfacies on the basis of the extent of the dolomitic replacement and the occurrence of pores:
- fully dolomitized tight samples (Figs. 3.A-F, 11.A-D),

- $\quad$ "fully" dolomitized tight samples with former pores cemented by anhydrite (Figs. 8.E-F, 11.E-F),

- $\quad$ "fully" dolomitized porous samples (Figs. 4.AD, 5.F, 8.A-D, 14.E-F),

- partly dolomitized tight samples (Figs. 5.C, 13. A-E),

- $\quad$ partly dolomitized porous samples with pores resulting from incomplete leaching (Figs. 13. F, 14.A-D).

The last category is the most interesting because it represents the intermediate stage between partly dolomitized tight samples (Fig. 13.AE), which have retained some calcitic parts (i.e., remaining allochem cores), and "fully" dolomitized porous or tight samples. These partly dolomitized porous samples (Figs. 13.F, 14.A-D) document how leaching proceeded with undolomitized allochem cores. Such leaching was not centripetal but, in the case of ooid cortices, it appears to affect discrete layers differently (Figs. 13.F, 14.AD). That could be related either to the original amount of organic matter in the ooid cortices or to their original magnesium content.

Some fracturing (Figs. 12.A, 15) postdates dolomitic replacement. High-temperature saddle dolomite and later anhydrite, i.e., cements, filled in such fractures (Figs. 12.A, 15), suggesting that the fractures were the pathway to high-temperature brines. However, leaching of calcitic remains, which postdates stratiform stylolites, also postdates such fractures and their cements (Fig. 12.A). 

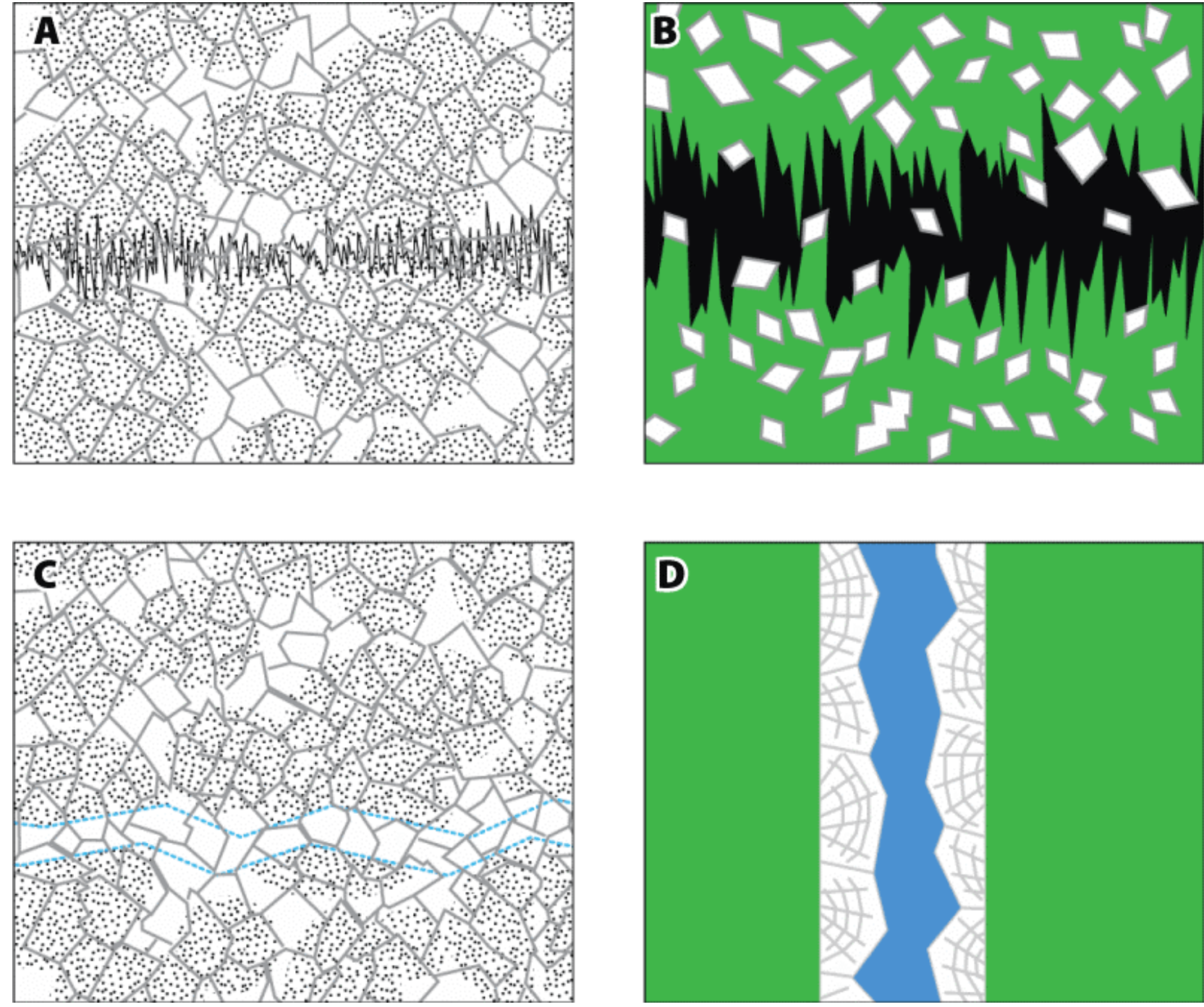

Figure 17: Pinda Group. A) Pressure-solution seam predating dolomitic replacement in a dolograinstone. B) Stratiform stylolite (? partly) postdating a limited dolomitic replacement in a slightly dolomitized mudstone. C) Fracture predating dolomitic replacement in a dolograinstone. D) Fracture predating dolomitic (baroque) cementation in a mudstone. Figure caption: White/light grey: dolomite; blue: porosity; green: micrite (i.e., microcrystalline calcite); black: insoluble residues (e.g., iron oxide, clay minerals, and organic matter).

In most cases, leaching of calcitic relicts of grains (Figs. 4.A-D, 5.F, 8.A-D, 10.C, 12.D-F) is commonly the last stage preceding the hydrocarbon reservoir charge (Fig. 16.A-C).

In any case, leaching of calcitic relicts of grains (e.g., micritic ooid cores, cortexes and nuclei) postdates all stratiform stylolites (Figs. 10.C, 12.F). Accordingly, leaching started at least below the first $400 \mathrm{~m}$ of burial and even possibly below the first $600 \mathrm{~m}$.

\section{Conclusions}

According to EICHENSEER et al. (1999), "From our integrated stratigraphic and geochemical study we see no strong evidence for deep burial dolomitization in the Lower Congo Basin, although fluid inclusion and isotope data suggest otherwise. The pervasively dolomitized reservoir section is best explained by early shallow dolomitization and carbonate dissolution". All of that, as well as STARK's hypotheses (1991), prove to be wrong. A forthcoming publication will show that, although their diagenetic model failed to account for some relationships listed below, the depositional model of EICHENSEER et al. (1999), which drew on GRANIER (unpublished reports), was in some degree valid.

Although our samples come from several wells, paragenetic sequences have very similar patterns:

- In mud-dominated fabrics (e.g., in the cap rock and in the remainder of the non-reservoir overburden), chemical compaction first occurred between 150 and $400 \mathrm{~m}$ of burial (see $\S 6$.). Although a limited dolomitic replacement is observed there too and slightly predates the chemical compaction (Fig. 17.B), it cannot be related in any sort to "early shallow dolomitization" because this replacement occurred in sediments typical of relatively deep-water environments with relatively low-sedimentation rates; 
- In grain-dominated fabrics (i.e., in reservoir units), first came early cementation that was locally responsible of some hardgrounds and lithoclasts derived from them. This stage documented by boring or encrusting organisms (see $\S 4$. ) is rare (Fig. 5.A-E);

- $\quad$ Some early fracturing (Figs. 3, 17.C), possibly related to the synsedimentary rafting of the Pinda structures on top of the Loeme salt, occurred during the episode of calcitic cementation. It postdates early phases of calcitic cementation (partly including syntaxial overgrowth of echinoderm remains);

- Still, in grain-dominated fabrics, mechanical compaction occurred in the first $150 \mathrm{~m}$-or ? less - of burial whereas first stages of chemical compaction occurred below the first 400 $\mathrm{m}$-or? less- of burial (see $\S 6$.). In the studied samples of the Pinda Group dolomitic replacement partly masked the weaker dissolution features present in calcitic precursors (Figs. 3, 4.A-D, 8.A-D), i.e., it postdates them. This dolomitic replacement should not be interpreted as "early shallow dolomitization" because it definitely is a case of burial dolomitization (>400 m)

- Some late fracturing, partly occluded by hightemperature saddle dolomite (Figs. 12.A, 17.D), also postdates dolomitic replacement;

- Leaching of calcitic remains postdates all stratiform stylolites (Figs. 10.C, 12.D-F). Accordingly, leaching started at least below the first $400 \mathrm{~m}$ of burial and even possibly below the first $600 \mathrm{~m}$. In most cases, leaching of calcitic grains (Figs. 4.A-D, 5.F, 8.A-D, 10.C, 12.E-F) was commonly the last stage preceding the hydrocarbon reservoir charge (Fig. 16. A-C). This leaching should not be interpreted as "early shallow (...) carbonate dissolution", because it obviously is a case of burial leaching (>600 m).

In the paragenetic sequence described above, first dolomitic replacement and then leaching postdate early stages ("fitted-fabrics and microstylolites": Fig. 17.A), and eventually later stages ("stratiform stylolites") of chemical compaction. The burial depth of the Pinda oil and gas reservoirs probably exceeded $150 \mathrm{~m}$ when dolomitization started whereas it should have being not less than $400 \mathrm{~m}$ with respect to leaching. Both processes represent burial diagenetic features and disprove the hypotheses of STARK (1991) and of EICHENSEER et al. (1999). In the alternative model discussed above, the source of $\mathrm{Mg}$ in the dolomitizing solutions was neither meteoric water, nor marine water, nor marine-derived brines but probably from the underlying Aptian Loeme Salt Group (GRANIER, 2009, and earlier unpublished reports). The incorporation of these new pieces of information help to complete the "new" stratigraphic and genetic model for the dolomitic Cretaceous Pinda reservoirs that will be presented in a forthcoming publication (GRANIER, nearing completion).

\section{Acknowledgements}

The author would like to thank Sonangol for having granted permission through an agreement dated April 13th, 2017, to use some of their material in this publication. He is very grateful to Isabel PolicARPo DA SILVA and Jean Colsoul who acted as facilitators in the agreement with Sociedade Nacional de Combustíveis de Angola Empresa Pública - Sonangol E.P. Thanks go to Trevor BURCHETTE and L. Bruce RAILSBACK for their constructive comments, to Phil SALVADOR for his help with an early version of this manuscript, to Robert W. ScotT for having checked the final English version, and to Dimas DIAS-BRITO for having translated the abstract into Portuguese. SEM photography in Figure 7.A was by Hermes DIAS BRITO of the UNESPetro. The author is solely responsible for the interpretations (and opinions) expressed here, which do not necessarily reflect those of Sonangol.

\section{Editorial notes}

1. Results presented hereafter question the "scientific" value of many "technical" papers published in professional journals (e.g., AAPG Bulletin, GeoArabia, and SPE publications) or book series (e.g., Schlumberger Well Evaluation Conference) because it is often not possible for external and independant researchers to duplicate observations or experiments based on proprietary data. The author is very grateful to Sociedade Nacional de Combustíveis de Angola Empresa Pública Sonangol E.P. for permission to re-use some material and to re-evaluate previous results.

2. It is unusual to list as separate bibliographic references internal oil company reports because this material is "unpublished" and its proprietary contents are not accessible to the vast majority of readers. However, the author assumed their dates of issue are indicative of the relative timing of the technical and scientific elements documenting the case studied.

\section{Bibliographic references}

Benson W.B., Sheridan R.E., Enos P., Freeman T., Gradsteln F.M., MurdmaA I.O., PAstouret L., SCHMIDT R.R., STUERMER D.H., WeaVer F.M. \& WORSTELL P. (1978).- 6. Site 392: South rim of Blake Nose. In : Benson W.B., SHERIDAN R.E., PAstouret L., Enos P., Freeman T., MurdmaA I.O., Worstell P. (ed.), Gradstein F.M., SCHMIDT R.R., WEAVER F.M. \& STUERMER D.H.Initial Reports of the Deep Sea Drilling Project, vol. XLIV, Washington D.C., p. 337-393.

DUNHAM R.J. (1962).- Classification of carbonate rocks according to depositional texture. In : HAM W.E. (ed.), Classification of carbonate 
rocks.- American Association of Petroleum Geologists, Memoir, Tulsa, vol. 1, p. 108-121.

EICHENSEER H.T., WALgenWITZ E R. \& BIONDI P.J. (1999).- Stratigraphic control on facies and diagenesis of dolomitized sequences (Pinda Group, Albian, offshore Angola).- AAPG Bulletin, vol. 83, no. 11, p. 1929-1958.

EMBRY A.F. \& KLovan J.E. (1971).- A Late Devonian reef tract on Northeastern Banks Island, N.W.T.- Bulletin of Canadian Petroleum Geology, Calgary, vol. 19, p. 730-781.

Evamy B.D. \& SheARMAN D.J . (1965).- The development of overgrowths from echinoderm fragments.- Sedimentology, vol. 5, no. 3, p. 211233.

Evamy B.D. \& SHEARMAN D.J. (1969).- Early stages in development of overgrowths on echinoderm fragments in limestones.- Sedimentology, vol. 12 , no. 3-4, p. 317-322.

FLÜGEL H. (2004).- Microfacies of carbonate rocks.- Springer, Berlin, $984 \mathrm{p}$.

Fourcade É. \& GRANIER B. (1989).- Age des carbonates de plate-forme du site 392A DSDP ( Leg 44), marge atlantique du continent nord américain.- Marine Geology, vol. 90, no. 3, p. 197 204.

Granier B. (1994).- Datation de la poronécrose des réservoirs et de la mise en place des hydrocarbures dans l'Oolithe du Callovien inférieur de Villeperdue (Bassin de Paris).- Nouvelles Géologiques, Total E.P., Paris La Défense, no. 17 , p. 102-112.

GRANIER B. (2009).- Decrypting the marine Albian succession in the Congo Basin (Congo and northern Angola).- 8th International Symposium on the Cretaceous System, Plymouth (September 6th-12th), Abstract 964, 2 p.

GRANIER B. (2014).- Borings and etchings in the Upper Bathonian-Lower Callovian oolite of the Paris Basin (France).- Carnets Geol., Madrid, vol. 14, no. 21, p. 461-469.

GRANIER B. (2017).- Brand new stratigraphic and genetic model for the dolomitic Cretaceous Pinda reservoirs in Angola. Part I - The Pinda of Angola, an integrated lithostratigraphic approach.- Carnets Geol., Madrid, vol. 17, no. 4, p. 105-127.

Granier B., Barbin V. \& Charollais J . (2014).- Significance of partial leaching in calcareous ooids: The case study of Hauterivian oolites in Switzerland.- Carnets Geol., Madrid, vol. 14, no. 22 , p. 471-481.

Granier B. \& STAFFELBACH C. (2009).- Quick look cathodoluminescence analyses and their impact on the interpretation of carbonate reservoirs. Case study of mid-Jurassic oolitic reservoirs in the Paris Basin.- Carnets Geol., Madrid, vol. 9, no. A07 (CG2009_A07), 14 p.

Gratier J .-P., Muquet L., hassañ R. \& Renard F. (2005).- Experimental microstylolites in quartz and modeled application to natural styIolitic structures.- Journal of Structural Geology, vol. 27, no.1, p. 89-100.
J ONES B. (2007).- Inside-out dolomite.- Journal of Sedimentary Research, vol. 77, p. 539-551.

LUCIA F.J. (1962). - Diagenesis of a crinoidal sediment.- Journal of Sedimentary Petrology, vol. 32, no. 4, p. 848-865.

Nicolaides S. \& Wallace M.W. (1997).- Pressure dissolution and cementation in an Oligo-Miocene non-tropical limestone (Clifton Formation), Otway Basin, Victoria. In: J AMES N.P. \& CLARKE J.A.D. (eds.), Cool-water carbonates.- Special Publications of SEPM, no. 56, p. 249-261.

RAILSBACK L.B. (2002).- An atlas of pressure dissolution features.- UGA Sedimentary Geochemistry Laboratory, University of Georgia, Athens. URL: http://www.gly.uga.edu/railsback/PDFindex 1.html

STARK D.M. (ed., 1991).- 1 Petroleum geology Geologia petrolífera. In: Avaliação de formações de Angola.- Well Evaluation Conference, Schlumberger, Paris, 1-95 p.

TOWE K.M. (1967).- Echinoderm calcite: Single crystal or polycrystalline aggregate.- Science (New Series), vol. 157, no. 3792, p. 10481050.

Zhang X.-M., Spiers C.J. \& Peach C.J. (2010).Compaction creep of wet granular calcite by pressure solution at $28^{\circ} \mathrm{C}$ to $150^{\circ} \mathrm{C}$.- JRG Solid Earth, vol. 115, no. B9, 18 p.

\section{Unpublished reports}

GRANIER B. (1985, unpublished).- Codification macrolithologique de carottes appliquée à l'étude du réseau macroporeux - Application au réservoir Pinda inférieur du champ de Palanca (Angola).- Société Nationale elf-Aquitaine (Production), Rapport de Stage, Pau, 28 p.

GRANIER B. (1990, unpublished).- Nouvelle nomenclature stratigraphique (séquentielle) de l'Albien de l'offshore angolais. Implications sédimentologiques et structurales.- Rapport SCOP 6, Société Nationale elf-Aquitaine (Production), Pau, Rapport SCOP 6, 14 p.

GRANIER B. (1991a, unpublished).- Application des concepts de la stratigraphie séquentielle à l'étude des réservoirs albiens (Pinda) du bloc 2, Angola.- Total, Saint-Rémy-lès-Chevreuse, Mémo CST/CARB 91-129.

GRANIER B. (1991b, unpublished).- Tentative d'établissement d'un modèle sédimentologique du Pinda sur la moitié sud du bloc 2, offshore angolais (60 puits).- Total, Saint-Rémy-lèsChevreuse, Mémo CST/CARB 91-208.

GRANIER B. (1992, unpublished).- Tentative d'établissement d'un modèle sédimentologique du Pinda (Albo - ? Cénomanien) sur la moitié sud du bloc 2 (50 puits), offshore angolais.- Total, Rapport Laboratoires no. 4850, Saint-Rémylès-Chevreuse, vol. I (text): 28 p.; vol. II (figures and appendices).

GrANIER B. \& GoY G. (1993, unpublished).- Pinda Formation, Block 2, Offshore Angola. Catalogue of microfacies of the Lower and Middle Pinda Formation, based on the cored intervals 
from 22 wells.- Total, Rapport Laboratoires no. 5143, Saint-Rémy-lès-Chevreuse, $10 \mathrm{p}$. (50 Pls.).

Granier B., GoY G. \& I MBert P. (1993, unpublished).- Pinda Formation, Block 2, Offshore Angola. Regional overview, based on the (re)appraisal of core analyses from 22 wells.Total, Rapport Laboratoires no. 5126, SaintRémy-lès-Chevreuse, vol. I (text): 56 p.; vol.
II (appendices); vol. III (11 Pls.).

Pabian-Goymeneche C., Sehans P. \& Granier B. (1986, unpublished).- Gisements du Pinda d'Angola (Volet Géologie). Codification lithologique et microtectonique de carottes appliquée au réseau poreux du réservoir carbonaté vacuolaire de Palanca.- Société Nationale elfAquitaine (Production), Rapport EP/S/EXP/ RAG/Lab.Pau no. 86/138RS, 20 p. 